\title{
10 Interpreting Hard Cases
}

THE LAST CHAPTER HAS LEFT US with a series of interpretative questions related to extraterritorial protection. The present chapter has the task of reducing the number of ambiguous outcomes as far as possible with the assistance of the interpretative norms in the Vienna Convention. In the first stage, the methodology inherent in Articles 31-2 VTC compelled us to regard the terms of each provision separately, admitting only a limited set of data. The second stage, with which this chapter begins, extends the scope of the interpretative operation, and complements the analysis of the ordinary meaning with an examination of, first, the context and, second, the object and purpose. Article 31 (2) VTC delimits what shall be regarded as the context of a treaty, and Article 31 (3) VTC enumerates what shall be taken into account 'together with the context'. What is to be understood by the 'object and purpose' is not developed further in the Vienna Convention, however. With the second stage, it is clear that we are beginning to shift from the sphere of legaltechnical arguments to that of qualitative argumentation.

Provided that the second stage fails to produce clear outcomes, the interpreter may resort to a third stage. A non-exhaustive enumeration of

(C) GREGOR NOLL, 2000 | DOI:10.1163/9789004461543_011

This is an open access chapter distributed under the terms of the CC BY-NC 4.0 license. 
the data which may be used in the third stage is contained in Article 32 VTC. Among them, we find the travaux préparatoires.

The rationale of the second and third stages is to resolve the conflict in interpretation persisting after the first stage. However, as pointed out earlier, the possibility remains that the interpretative divide will become more profound instead. This is where a conflict is transposed from a qualitative to a meta-legal level.

\subsection{Protection: Implicit Prohibitions of Refoulement}

Recalling our earlier reflections on the terms of Article 3 ECHR and Article 7 ICCPR, the question of how the term 'subjected' in each of these prohibitions of ill-treatment should be interpreted became unavoidable. The term could be understood to denote either 'subjected on the territory of the Contracting Party' or 'subjected on the territory of the Contracting Party or elsewhere'.

\subsubsection{Article 3 ECHR}

\subsubsection{The Reasoning of the European Organs}

As clarified earlier, the European organs have chosen the latter option. In constant case-law, the Court has stated that Article 3 ECHR is applicable in the context of removal. ${ }^{1144}$ More specifically, this provision is violated

${ }^{1144}$ For a recent and carefully argued analysis of the case law of the European organs, see S. Karagiannis, 'Expulsion des étrangers et mauvais traitements imputables à l'état de destination ou à des particuliers', 10 Rev.trim.dr.h. 37 (1999). For general overviews of non-refoulement provisions in human rights law, including the case law under the ECHR, see R. Plender and N. Mole, 'Beyond the Geneva Convention: constructing a de facto right of asylum from international human rights instruments', in F. Nicholson and P. Twomey (eds), Refugee Rights and realities: evolving international concepts and regimes (1999, Cambridge University Press, Cambridge), pp. 81-91; T. Hartl, Das völkerrechtliche Refoulementverbot abseits der Genfer Flüchtlingskonvention (1999, Peter Lang, Frankfurt am Main), pp. 39-135. See also H. Fourteau, L'application de lárticle 3 de la Convention européenne des droits de l'bomme dans le droit interne des États members (1996, L.G.D.J., Paris), pp. 211-65. For a comparison between the case law of the ECHR and of the CAT Committee, see J. Suntinger, 'Article 3 ECHR', Austrian Yearbook of International Law (1996). 
where 'substantial grounds have been shown for believing that the person concerned faces a real risk of being subjected to torture or to inhuman or degrading treatment or punishment in the country to which he or she was returned'. ${ }^{1145}$

The present argumentation, elaborated by the European organs throughout decades, assumes that the decision of removal and the expected violation of human rights in a third state are indivisible. Although this assumption is universalist, we shall see that the Court was careful enough to prepare for future limitations of its stance by incorporating particularist retreat positions. In the following, we shall track the pattern of argumentation as it emanates from the reasoning of the Court.

In Soering, already identified as the landmark case in which extraterritorial protection under Article 3 ECHR was introduced ${ }^{1146}$, the Court found it necessary to argue for the applicability of this provision in greater detail. We shall follow this trail of argumentation, keeping in mind that its references to extradition apply mutatis mutandis to all other forms of removal ${ }^{1147}$ and complementing it, where necessary, with the dicta from later judgements.

Typically, the Court proceeds in eight steps, weaving together its conclusion by alternating between the affirmation of rules and the reduction of their scope. First, it acknowledges the sovereign right of states to control immigration. ${ }^{1148}$ Second, it states that the ECHR contains no right to immigration or to asylum. ${ }^{1149}$ These are two major affirmations, seemingly conceding to the particularist interests of the state. We may conclude that, taken in an isolated fashion, a decision to remove an alien does not contravene the Convention. However, in a third step, the Court reduces the reach of both affirmations by underscoring that the state right to control is not an absolute one. It has to be exercised with

1145 Nsona $v$. the Netherlands, Judgment of 28 November 1996, Reports 1996 V, para. 92, with further references.

1146 See text accompanying note 1125 above.

1147 A parallel reasoning was first applied in the Cruz Varas case, turning on the removal of an asylum seeker. Cruz Varas, paras 69 and 70 . Compare also the principles spelt out in Nsona, para. 92 (b).

1148 Vilvarajah, para. 102; Nsona, para. 92.

1149 Ibid. For an enumeration of cases, see Council of Europe, 1984, pp. 23-4. It should be borne in mind that the same is true for the 1951 Refugee Convention. 


\title{
CHAPTER 10
}

due regard to those human rights obligations flowing from Section 1 of the ECHR. Although it represents a necessary part of the Court's argumentation, this step is not documented in Soering or any other case before the Court. Here, we may rely on the expressions it has found with the Commission on a large number of occasions:

\begin{abstract}
Whereas under general international law a State has the right, in virtue of its sovereignty, to control the entry and exit of foreigners into and out of its territory; and whereas it is true that a right or freedom to enter the territory of States, members of the Council of Europe, is not, as such, included among the rights and freedoms guaranteed in Section I of the Convention; whereas, however, a State which signs and ratifies the European Convention of Human Rights and Fundamental Freedoms must be understood as agreeing to restrict the free exercise of its rights under general international law, including its right to control the entry and exit of foreigners, to the extent and within the limit of the obligations which it has accepted under that Convention. ${ }^{150}$
\end{abstract}

That is, the implementation of a decision to remove a foreigner can conflict with obligations in Section I ECHR in certain cases. ${ }^{151}$

Next, the Court prepares the ground for the ensuing interpretation by adducing, fourth, a contextual and, fifth, a teleological argument.

In developing the contextual argument, the Court reverses the order of things reigning in the earlier steps: now, affirmation works for the universalist claimant, and reduction for the particularist responding state. As part of the context, the Court introduces Article 1 ECHR, which provides that 'the High Contracting Parties shall secure to everyone

1150 The Commission has made use of this paragraph in more than a dozen cases between the fifties and eighties. It was first used in Dec. Adm. Com Ap. 434/58, 30 June 1959, YB II, p. 354 at 372; Coll. 1. For an overview of other cases where it has been used, see Council of Europe, 1984, p. 118.

1151 Two types of cases can lead to such a conflict. Firstly, removal may directly affect a person's human rights as enshrined in the ECHR. This could be the case if the action of removal separates him from family members in the removing country. It can also be referred to cases where a gravely ill person is exposed to transport in spite of negative consequences for her health. Such conflicts relate to circumstances within the jurisdiction and, as a rule, on the territory of the removing state. They are not relevant for the purpose of this chapter. Instead, we shall focus on the second type of case, where a violation of a right enshrined in the ECHR is anticipated to take place in the country to which a person is removed. 
within their jurisdiction the rights and freedoms defined in Section I' ${ }^{1152}$ Now, the Court shifts the focus of argumentation: suddenly, the negative obligation of not 'subjecting' is traded off for the positive obligation of 'securing'. The importance of this exchange for the outcome of the Court's reasoning can hardly be overestimated. As if it has been frightened by its own radical universalism, the Court rushes from an affirmation of the relevance of this positive obligation to its immediate limitation:

In particular, the engagement undertaken by a Contracting State is confined to "securing" ("reconnaitre" in the French text) the listed rights and freedoms to persons within its own "jurisdiction". Further, the Convention does not govern the actions of States not Parties to it, nor does it purport to be a means of requiring the Contracting States to impose Convention standards on other States. Article 1 (art. 1) cannot be read as justifying a general principle to the effect that, notwithstanding its extradition obligations, a Contracting State may not surrender an individual unless satisfied that the conditions awaiting him in the country of destination are in full accord with each of the safeguards of the Convention. ${ }^{1153}$

Although the judges denied the existence of an obligation embracing the individual's future treatment in another state, they underscored again that the liberty of states was not unfettered. In the end, Contracting Parties were not absolved 'from responsibility under Article 3 [...] for all and any foreseeable consequences of extradition suffered outside their jurisdiction'. ${ }^{1154}$ No further motivation is given, and the exact delimitation of state obligation and state freedom of action under Article 1 ECHR remains obscure. At most, the quoted passage would suggest that the level of protection is lower in a context involving extraterritorial threats than in a context involving domestic threats. ${ }^{1155}$

1152 Soering, para. 86. See also European Commission of Human Rights, Decision of 12 March 1984, Appl. 10479/83, Kirkwood v the United Kingdom, D \& R 37 (1984) p. 158, at p. 183.

1153 Soering, para. 86.

1154 Soering, para. 86.

1155 This implies that the Court introduces a two-level hierarchy of rights under the Convention, which is not provided for by its wording. Needless to say, the erection of such a hierarchy begs theoretical as well as practical questions. 


\section{CHAPTER 10}

Still, the contextual argument had increased rather than resolved ambiguity: apart from the question what 'subjecting' in Article 3 ECHR means, the Court also had to take a stand on the interpretation of 'securing' in Article 1 ECHR. At this stage, the Court switched over to the teleological level. It took recourse to the special character of the ECHR as a treaty for the collective enforcement of human rights and reminded observers of the interpretative principles developed in the Court's earlier case law.

Thus, the object and purpose of the Convention as an instrument for the protection of individual human beings require that its provisions be interpreted and applied so as to make its safeguards practical and effective [...] In addition, any interpretation of the rights and freedoms guaranteed has to be consistent with "the general spirit of the Convention, an instrument designed to maintain and promote the ideals and values of a democratic society". 1156

The level of abstraction is rather high in these lines, striking a single chord of affirmation. The absence of clear delimitations ratione loci should not keep the Court from meting out effective protection to claimants. And the promotional dynamics inherent in the Convention would seem to motivate an extension rather than a restriction of protection accorded under it. The ambiguity harvested in the contextual argument is converted into freedom, and the telos of the Convention suggests that this freedom should be used for the sake of universalism.

In the sixth step, the Court turns more technical again, still maintaining the theme of universalist affirmation. Article $3 \mathrm{ECHR}$ is identified as absolute and, given the wording of Article 15 ECHR, nonderogable. ${ }^{1157}$ Thus, it is identified as enshrining 'one of the fundamental values of the democratic societies making up the Council of Europe'. ${ }^{1158}$ Although the Court does not spell it out, this provision would seem to be one of the best candidates for the promotional agenda of the Convention. In the same step, the Court tackles the issue whether the prohibition of refoulement under Article 3 CAT should be seen as lex specialis,

\footnotetext{
1156 Soering, para. 87.

1157 Soering, para. 88.

1158 Soering, para. 88.
} 
possessing some form of regulatory monopoly for cases of removal. This is denied by the Court: 'The fact that a specialised treaty should spell out in detail a specific obligation attaching to the prohibition of torture does not mean that an essentially similar obligation is not already inherent in the general terms of Article 3 [...] of the European Convention'. ${ }^{1159}$ To underpin that conclusion, the Court refers to the telos of the Convention, as expressed in the preamble, and the telos of Article $3 \mathrm{ECHR}$ itself.

In the seventh step, the Court formulates the problem of a traditional limitation of the Convention's protective scope. It acknowledges that it usually does not pronounce itself on potential violations of the ECHR. Reducing the scope of this reduction, it introduces an exception for cases where the suffering risked would be 'serious and irreparable'. ${ }^{1160}$

Finally, in the eighth and last step, the Court claims to infer the responsibility of the removing state directly from the act of the third state:
The establishment of such responsibility inevitably involves an assessment of conditions in the requesting country against the standards of Article 3 (art. 3) of the Convention. Nonetheless, there is no question of adjudicating on or establishing the responsibility of the receiving country, whether under general international law, under the Convention or otherwise. In so far as any liability under the Convention is or may be incurred, it is liability incurred by the extraditing Contracting State by reason of its having taken action which has as a direct consequence the exposure of an individual to proscribed ill-treatment. ${ }^{1161}$

With this final affirmation of the non-divisibility of acts leading to violations of human rights, the Court has taken a clear stand for the universalist cause. However, the universalist result is derived from walking a path of particularist 'principles'. In the first and second steps, particularism is made the starting point of the whole argumentation. By denying the existence of a universalist 'principle' in the fourth step, it relegates universalism to a status of exception and keeps the particularist door open for future corrections. The same is true for the seventh step, where a particularist rule is generally upheld, but complemented once

\footnotetext{
1159 Ibid.

1160 Soering, para. 90.

1161 Soering, para. 91.
} 


\section{CHAPTER 10}

more with a universalist exception. By doing so, the Court avoided tying itself to a paradigm, which would reduce its options in future cases. For the Court, straddling divergent paradigms is a rational strategy. True enough, it strikes against the predictability of outcomes. However, this cost is borne by the Contracting Parties to the ECHR and the individuals under their jurisdiction rather than the Court itself.

\subsubsection{Two Critics of the European Organs}

In the foregoing, it could be shown that the reasoning developed by the European organs fails to deliver a stringent theory on the territorial reach of the human rights enshrined in Section I of the ECHR. The path chosen by the organs to affirm the existence of state responsibility for extraterritorial violations entailed new ambiguities. Moreover, the organs limit themselves to stating the choices they made instead of giving reasons for doing so. Probably, this was a wise thing for a monitoring body to do, but it does not relieve the doctrinal writer from an obligation to search for a more conclusive and forceful interpretation.

Making recourse to the methodology of interpretation expounded above, we note that other contextual and teleological arguments can be adduced, and that the ones invoked by the European organs can be used differently. As it pleased the organs to reach a universalist outcome, and as this outcome has been praised, condoned or tacitly accepted by numerous doctrinal writers ${ }^{1162}$, it seems appropriate to let its critics come forward. ${ }^{1163}$

Reichel is one of them. ${ }^{1164}$ Proceeding in two steps, he concludes that Article 3 ECHR possesses no extraterritorial reach. First, he reformulates the problem, asking whether the legal character of action taken by one state (expulsion) can be determined by those acts of another state (torture), for which they are a causal precondition. ${ }^{1165}$ If this is the case, international law would contain a state duty to react on other states'

\footnotetext{
1162 For a comprehensive overview, see Maaßen, 1997, pp. 117-20.

1163 Apart from the criticism voiced by Reichel and Maaßen, dealt with extensively below, a less elaborate critique can be found with G. H. Gornig, Das Refoulement-Verbot im Völkerrecht (1987, Braumüller, Wien), p. 34.

1164 E. Reichel, Das staatliche Asylrecht 'im Rabmen des Völkerrechts'. Zur Bedeutung des Völkerrechts für die Interpretation des deutschen Asylrechts (1987, Duncker \& Humblot, Berlin), pp. 171-80.

${ }^{1165}$ Reichel, 1987, pp. 173-7.
} 
wrongful acts by refraining from any action objectively promoting such acts. This duty, professes Reichel, is not generally incorporated into international law and cannot said to be 'the rule'. Therefore, at the time of its drafting, one could not assume that Article 3 ECHR would include protection from extraterritorial threats. However, he continues, international law has developed. As evidence, he cites Article 27 of the ILC Draft Articles on State Responsibility, outlawing aid or assistance by a state to another state for the commission of an international wrongful act. ${ }^{1166}$ Based on the Barcelona Traction and Teheran Hostages Cases, Reichel finds that the observance of fundamental legal obligations is in the interest of all states and that all states are called upon to avert the damages emanating from their violation. Given that the prohibition of torture forms part of these fundamental legal obligations, Reichel comes to the intermediary conclusion that an extensive interpretation of Article 3 ECHR would correspond to the recent developments sketched by him.

In the second step, however, Reichel approaches the problem from a different tack. ${ }^{1167}$ As Article 5 (1) (f) ECHR allows detention for the purposes of expulsion, Reichel deduces the general permissibility of removing aliens. A reference to the prohibition of collective expulsion in Article 4 of the Fourth Protocol is taken as a sign that other forms of expulsion are allowed under the Convention. These two deductions e contrario are complemented by a historical argument. Attempts to include a right to asylum in the rights catalogue of the ECHR and its protocols failed repetitiously. Reichel names specific attempts to include a right to seek and enjoy asylum from persecution as well as a prohibition of refoulement to persecution into the second Additional Protocol to the ECHR, which failed to muster the necessary support from governments in $1961 .{ }^{1168}$ Reichel suggests that the absence of regulation proves that the state right to expel aliens is principally unfettered. This issue is simply not regulated in the Convention, and any attempts to compensate this lacuna by analogy would raise substantial doubts.

The pattern pursued by Reichel can be described as an initial affirmation of a universalist reading followed by an affirmation of the particularist perspective through contextual and historical arguments. The latter are allowed to dominate, being considered as closer to the actual will

\footnotetext{
1166 YILC 1980, Vol. II, Part 2, p. 30.

1167 Reichel, 1987, pp. 177-9.

1168 Reichel, 1987, p. 178.
} 


\section{CHAPTER 10}

of the contracting parties. However, as deductions e contrario lack precision, and the second step relies on such deductions, his conclusion suffers from a lack of compelling force. As indicated earlier, this deficiency is shared by the argumentation advanced by the Court.

Eleven years after Reichels contribution to the debate, an outright rejection of the European organ's case law under Article 3 ECHR was attempted by Maaßen, who was able to integrate the Courts judgements since the 1989 Soering case into his analysis. Maaßen advances three lines of argument. The first deals extensively with the issue of state responsibility.

From the outset, Maaßen makes himself a partisan of particularism by explicitly describing removal to a country where the individual is faced with a human rights violation as an act consisting of two parts. The first part consists of removal proper, which he is endowing with a legality as such'1169, and the second of the violation to which the individual is exposed in the receiving country. In a footnote, he motivates this strict distinction by pointing out that both parts presuppose their own voluntary decision and, as a rule, strive separately for different goals. ${ }^{1170}$ We shall have reason to return to this issue in some detail below. ${ }^{1171}$

Maaßen states that the delict of aiding another state in the assistance of an internationally wrongful act lacks a basis in treaty law or custom. Moreover, even if it existed, it would fail to apply in the case in point: drawing a parallel from German criminal law, Maaßen states that the wrongful act must have been accomplished to trigger responsibility for aiding and abetting. As the human rights violation has not taken place at the time of removal, there cannot be any state responsibility for aiding and abetting. ${ }^{1172}$ Next, Maaßen considers whether the notion of state responsibility for dangerous activities could apply to removal cases. Claiming that removal is a neutral act per se, he excludes this notion as a basis for an extensive interpretation of Article 3 ECHR. ${ }^{1173}$ In the final

\footnotetext{
1169 Maaßen, 1997, p. 121 and p. 131.

1170 'Daß es sich hier um verschiedene Vorgänge handelt, kann man schon daraus entnehmen, daß beide Vorgänge einen eigenen Willensentschluss benötigen und in aller Regel getrennt zu einem unterschiedlichen Ziel hinstreben.' Maaßen, 1997, p. 126, note 376.

1171 See chapters 10.1.1.2 and 10.1.1.3 below.

1172 Maaßen, 1997, p. 124.

1173 Ibid.
} 
analysis, Maaßen ties state responsibility to territorial sovereignty rather than jurisdiction, which implies another reaffirmation of the particularist perspective. ${ }^{1174}$

The second line of argument largely reiterates the contextual and historical arguments already expounded by Reichel, complemented by a reference to Article 1 of the Seventh Protocol. ${ }^{1175}$ Here, Maaßen follows Reichel's model by concluding e contrario a) that the state right to expel aliens is only limited by provisions expressly dealing with that matter and b) that the absence of a right to asylum in the ECHR and its protocol implies that a right of extraterritorial protection must not be interpreted into Article 3 ECHR.

The third line of reasoning points at a number of consequences which an extensive interpretation of Article 3 ECHR would trigger.

1. Contracting States would also be obliged to admit persons claiming a risk of human rights violation in their country of origin.

2. Apart from Art. $3 \mathrm{ECHR}$, even other articles will trigger protection from refoulement.

3. Protection from refoulement cannot be limited to violations by agents of the third state, but would also cover violations by non-state agents.

4. Apart from removal, even other forms of state action entailing human rights violation by third states would lead to liability.

1174 Maaßen, 1997, p. 126.

1175 Protocol No. 7 to the European Convention for the Protection of Human Rights and Fundamental Freedoms, Strasbourg, 22 November 1984, E.T.S. No. 117. Art. 1 reads as follows:

'1. An alien lawfully resident in the territory of a State shall not be expelled therefrom except in pursuance of a decision reached in accordance with law and shall be allowed:

a) to submit reasons against his expulsion,

b) to have his case reviewed, and

c) to be represented for these purposes before the competent authority or a person or persons designated by that authority.

2. An alien may be expelled before the exercise of his rights under paragraph 1(a), (b) and

(c) of this Article, when such expulsion is necessary in the interests of public order or is grounded on reasons of national security.' 


\section{CHAPTER 10}

5. State liability would not be restricted to violations abroad, but also cover violations by private agents within the territory of the Contracting State. ${ }^{1176}$

According to his estimation, these consequences are devastating in the sense that they lead to an overburdening of reception states. He concludes that the Court has exceeded its competencies by endowing Article 3 ECHR with a content which the legislator-i.e. state parties to the ECHR-did not want it to have. ${ }^{1177}$

By comparison, Maaßen's argumentation is far less dialectical than the one pursued by Reichel, which weakens its capacities to integrate and consume opposed arguments. With Maaßen, everything flows from the initial affirmation of separated state responsibilities, enticing him to take a conservative approach to the evolving law of state responsibility. However, his insistence on the issue of state responsibility points to an interesting facet that merits further discussion.

\subsubsection{Methodological Appraisal}

At this point of the discussion, we have achieved an overview of the main arguments used by the European organs and two of its critics in what could be regarded as a debate on the proper interpretation of Article 3 ECHR. To what extent do they fit into the framework of the general rule of interpretation in the Vienna Convention? To be sure, neither the European organs nor its critics appear to be overtly concerned with following the interpretative norms of the Vienna Convention. There seems to be a consensus that the mere wording of Article $3 \mathrm{ECHR}$ is insufficient to produce clarity, as all of the named discussants proceed to other means of interpretation. As shown above, this is perfectly in line with the methodology derived from the Vienna Convention. ${ }^{1178}$ With regard to the context, all discussants refer to further articles in the ECHR, which is fully in line with Article 31 (2) VTC.

Additionally, both critics invoke rights enshrined in Protocols to the ECHR (Reichel refers to Article 4 of the Fourth Protocol; Maaßen refers

\footnotetext{
1176 Maaßen, 1997, pp. 129-34.

1177 Maaßen, 1997, p. 128.

1178 See chapter 9.3 above.
} 
additionally to Article 1 of the Seventh Protocol). However, not all parties to the ECHR are parties to the named protocols. ${ }^{1179}$ Therefore, the Fourth and the Seventh Protocol do not represent 'rules of international law applicable in the relations between the parties' in the sense of Article 31 (3) (c) VTC. ${ }^{1180}$ Furthermore, it would be hard to qualify the Protocols as 'subsequent practice in the application of the treaty which establishes the agreement of the parties regarding its interpretation' in the sense of Article 31 (3) (b) VTC. Even if the Protocols had qualified under the latter norm, it merits recalling that they only replicate the ambiguity of the ECHR. This runs counter to the requirement that practice establish 'the agreement of the parties regarding' the interpretation of Article 3 ECHR. Thus, the Protocols do not form part of the context of Article 3 ECHR.

By contrast, the rules of state responsibility referred to by the two critics and the state right to control the entry of aliens referred to by all discussants are part of the context as defined in Article 31 (3) (c) VTC. As customary international law, they are applicable in the relations between all State Parties to the ECHR.

Generally, the references to the object and purpose of the ECHR or its Article 3 fit into the framework of Article 31 (1) VTC, although an observer will note that the Court adduces its own principles of interpretation without making the nexus to the telos of the ECHR clear. ${ }^{1181}$

The decisive argument in both critiques is the intentional abstention by the Contracting Parties to stipulate a right to asylum (taking the place of the second argument in each argumentation). However, in the manner of presenting it, both critics commit a serious methodological mistake. Both Reichel and Maaßen fail to separate the context from the legislative history of the Convention and its Protocols. When arguing for an

1179 A list of state parties to the Fourth and Seventh Protocols is available at the website of the Council of Europe: <http://www.coe.fr/tablconv/46t.htm> and <http:// www.coe.fr/tablconv/117t.htm > (accessed on 26 April 00).

1180 Emphasis added. Accord: Yasseen, 1976, p. 63. But see: Dissenting Opinion of Judge Fitzmaurice in the Guzzardi Case, where he interpreted Art. 5 ECHR in the context of Art. 2 (1) of the Fourth Protocol (which the responding state had not ratified). ECtHR, Guzzardi vs. Italy, Series A, No. 39, p. 51. With all due respect for the pragmatic position taken by Judge Fitzmaurice, one must recall that it is not supported by the text of Art. 31 VTC. See Fastenrath, 1991, p. 183 note 728 for further examples where the limits of Art. 31 (3) (c) VTC were trespassed in case law or rejected by doctrinal writers.

1181 See text accompanying note 1156 above. 


\section{CHAPTER 10}

intentional omission of a right to asylum, they not only rely on the existing articles of the Convention, which are part of the context according to Article 31 (2) VTC, but also on the defeated attempts to include an asylum provision into the Convention framework. To be sure, the latter data are not part of the context under Article 31 (3) (c) VTC. ${ }^{1182}$ Neither can they be subsumed under Article 31 (3) (b) VTC as a 'subsequent practice in the application of the treaty which establishes the agreement of the parties regarding its interpretation'. The abstention of pursuing a legislative project further does not amount to a practice in the sense of that provision. Moreover, numerous indications contradict the establishment of an unambiguous practice in the sense of Article 31 (3) (b) VTC. ${ }^{1183}$ Falling outside the notion of context, these data must be considered as part of the legislative history. As such, they may be used exclusively for the confirmation of an interpretation derived from the second stage or for further clarification, if the second stage fails to render the necessary clarity. ${ }^{1184}$ Both critics disregard this rule. ${ }^{1185}$ Neither of them is able to show that the second stage has produced a result a) sufficiently clear to be the subject of confirmation in the third stage or b) which leaves the meaning ambiguous or obscure or leads to a result that is manifestly absurd or unreasonable. Therefore, it is simply not warranted to proceed to the third stage.

Further, they fail to pursue the third stage to its end: there is no indication that the authors looked into those parts of the travaux specifically dealing with Articles 1 and 3 ECHR. This would have

1182 'The context for the purpose of the interpretation of a treaty shall comprise, in addition to the text, including its preamble and annexes: [...] any relevant rules of international law applicable in the relations between the parties.'

${ }^{1183}$ E.g. Resolution 14/67 of 29 June 1967, cited in Reichel, 1987, p. 178 note 49. One should also consider that some Contracting Parties to the ECHR have introduced domestic protection categories that correspond to the case law of the European organs under Art. 3 ECHR. In the Swedish Aliens Act, a protection category drawing on the protective ambit of the ECHR is contained in Chapter 3 Section 3, para. 1, and a corresponding prohibition of refoulement can be found in Chapter 8 Section 1 . According to Section 53 (4) of the German Aliens Act, an alien may not be removed, if removal contravenes the ECHR. The current deliberations on subsidiary protection in the EU Council should also be recalled (see note 1203 below).

1184 Art. 32 VTC.

${ }^{1185}$ Maaßen develops the historical argument under the heading 'Context of significance'. (Bedeutungszusammenhang), which is at odds with the structure flowing from Arts 31 and 32 VTC. Maaßen, 1997, p. 127. 
revealed inter alia that earlier drafts of Article 1 ECHR contained a limitation to persons 'residing within' Contracting Parties, which was dropped in favour of the present wording, with the express intent of widening the scope of application of the Convention. ${ }^{1186}$ Accordingly, the critics' approach to the supplementary means of interpretation was a selective one.

In addition, Maaßen's third argument relating to the consequences of an extensive interpretation has no place in the methodological framework of Articles 31 and 32 VTC. Leaving aside the question whether his description of consequences is correct ${ }^{1187}$, it remains unclear whether he adduces those within the framework of the second stage or as a supplementary means of interpretation.

\subsubsection{Reinterpreting Article 3 ECHR}

The reasoning of the European organs, the alternative interpretations offered by two of its critics and our own methodological appraisal of both have endowed us with a tool box of rather diverse arguments. We have criticised the critics, and to some extent even the European organs, for deviating from the framework set by the Vienna Convention. The question is whether following this framework would have produced a determinate outcome and, if so, what its content would be. What we shall attempt in the following is a reinterpretation of Article 3 ECHR, avoiding the errors committed by both the Court and its critics. As the outcome will be decisive for the protection issue as well as the issue of access, the following argument indeed represents the essence of this chapter.

\footnotetext{
1186 See e.g. Report of the Sub-Committee instructed to make a preliminary study of the amendments proposed by the members of the Committee of Experts (5 February 1950): 'Since the aim of this amendment is to widen as far as possible the categories of persons who are to benefit by the guarantee contained in the Convention, and since the words "living in" might give rise to a certain ambiguity, the Sub-Committee proposes that the Committee should adopt the text contained in the draft Covenant of the United Nations Commission: that is, to replace the words "residing in" by "within its jurisdiction". As quoted in Council of Europe, Preparatory work on Article 1 of the European Convention on Human Rights, Strasbourg, 31 March 1977, Court (77) 9.

1187 In a number of respects, his analysis of consequences is seriously flawed. For a critique, see G. Noll, 'Book review. Hans-Georg Maßßen, Die Rechtsstellung des Asylbewerbers im Völkerrecht', 67 NJIL 371 (1998), pp. 374-8.
} 


\section{CHAPTER 10}

Starting out with the context of Article $3 \mathrm{ECHR}$, we note that five sets of data have been tenably invoked hitherto:

1. Article 1 ECHR, obliging Contracting Parties to 'secure' inter alia the right enshrined in Article 3 ECHR to persons within its 'jurisdiction';

2. Article 5 (1) (f) ECHR, regulating the legality of detention in the context of expulsion;

3. the state right to control the entry of non-citizens;

4. the absence of an explicit right to asylum in the Convention; and

5. the law of state responsibility.

In consecutive order, the amount of data contained in each set increases, and so does the distance to the provision to be interpreted. Simultaneously, the precision in argumentation decreases in a corresponding fashion.

Ad 1): Article $1 \mathrm{ECHR}$ is a single norm sentence, connected explicitly to Article 3 ECHR by a reference to 'the rights and freedoms defined in Section 1', of which Article 3 ECHR forms part. The amount of additional data provided by this provision is limited but as earlier noted, it forces the interpreter to take a stand on the extension of the term 'to secure'.

Ad 2): The nexus between Articles 5 (1) (f) and 3 ECHR is much more remote: the former provision enounces conditions under which detention may be used to deny entry to or to remove aliens. There is no explicit linkage between the provisions, and their thematic relationship is of a rather limited character. Article 5 (1) (f) ECHR would only be contextually useful if it had stated that, save for detention explicitly prohibited by it, all other forms of immigration control are permissible under the ECHR. Quite understandably, this is not the case. The fact that Article 5 (1) (f) ECHR names denial of entry and removal among the criteria for permissible forms of detention cannot be extrapolated to the conclusion that denial of entry and removal are per se unaffected by the rights and freedoms stated in Section I. ${ }^{1188}$ If immigration control had been offered the carte blanche of absolute permissibility under the ECHR, inhuman treatment during expulsion would also be beyond the reach of

${ }^{1188}$ Had Art. 4 of the Fourth Protocol and Art. 1 of the Seventh Protocol been part of the context, the same argumentation would have applied to them. 
the Convention. This is clearly fallacious, and none of the critics takes that position. ${ }^{1189}$ By conclusion, an e contrario deduction based on Article 5 (1) (f) ECHR is too imprecise and cannot help to determine the proper meaning of Article 3 ECHR. It entices the interpreter to reasoning out of the negative, wich entails a very large amount of additional data to be handled.

Ad 3): The state right to control the entry of non-citizens is thematically close to the interpretative issue at stake here. This right forms part of customary international law, and is therefore part of the context of Article $3 \mathrm{ECHR} .{ }^{1190}$ It is a positive right and, at first sight, this makes it easier to handle than the sets of data introduced under 2) and 4). However, the control right is not an absolute one; it has to be exercised with due regard to the stipulations of human rights law. ${ }^{1191}$ Therefore, it would be tautological to determine the impact of human rights law by recurring to the state right to control. Where it is invoked by proponents of a particularist interpretation, it is-consciously or not-endowed with the character of a residual trump: everything not explicitly regulated by human rights law is regulated by the state right to immigration control. International law features neither a demand for explicitness on the limitations through human rights, nor does it offer a hierarchical order putting state rights on a higher echelon than human rights. ${ }^{1192}$ Where the

${ }^{1189}$ See Maaßen, 1997 , p. 220 , explicitly stating that the conditions of removal must not contravene Art. 3 ECHR.

1190 See Art. 31 (3) (c) VTC.

1191 'A State has the competence to control and to regulate the movement of persons across its borders. This competence is not absolute. It is limited by the right of individuals to move across borders and by the obligations of the State that arise from generally accepted principles of international law and applicable international agreements.' Sohn and Buergenthal, 1992, p. 1.

1192 Bernhardt states explicitly that 'the often-invoked rule that treaties should be interpreted restrictively and in favour of State sovereignty can no longer be considered valid'. R. Bernhardt, 'Interpretation in International Law', in R. Bernhardt (ed.), Encyclopaedia of Public International Law (1992), Volume I (1992), pp. 1416-26, at p. 1421. Elsewhere, he notes that 'the in dubio mitius rule is not even mentioned in the Vienna Convention'. Ibid. at p. 1419. Given the post-war proliferation of human rights norms, the disappearance of this interpretative rule makes sense. Where treaties aim at stipulating benefits for third parties not represented under treaty negotiations, the duty-minimising presumption of bilateral international law is no longer appropriate. Moreover, inquiring into the precise content of 'mitius' brings us back to the conflict between universalism and particularism: does it serve the long-term interests of state to deflect victims of human rights violations, or is the opposite true? 


\section{CHAPTER 10}

argument of the state right to immigration control is endowed with such a trump function, it is merely the outflow of a political choice made by the interpreter. To conclude, the amount of data introduced by this argument is very large, and so is the risk of tautological reasoning.

Ad 4): The absence of a right to asylum in the ECHR also entails a reasoning out of the negative and shares the problems explained under ad 2). This absence forms the base of Reichel's and of Maaßen's second argument, providing another example of fallacious reasoning e contrario. The logical structure of their argument can be reduced to the following syllogism:

Premise 1: An implied right to extraterritorial protection under Article 3 ECHR is identical with the stipulation of a right to asylum, as suggested in the 1961 Proposal. ${ }^{193}$

Premise 2: $\quad$ The right to asylum, as suggested in the 1961 Proposal, has not been laid down in the ECHR.

Conclusion: There is no implied right to extraterritorial protection under Article 3 ECHR.

Quite obviously, the first premise is flawed. The right to asylum as specified in the 1961 Proposal is far from being congruent with the potential scope of extraterritorial protection under Article $3 \mathrm{ECHR}$. The former contains exceptions, while the latter does not. The former is characterised by the notion of persecution, while the latter hinges on the threat of torture, inhuman or degrading treatment or punishment. These forms of mistreatment are only a fraction of all conceivable practices amounting to persecution. Finally, the rejection of the 1961 Proposal may have taken place for many reasons. It is not warranted to conclude that the non-adoption of the right to asylum implies that the Contracting Parties simultaneously intended to limit the extraterritorial reach of the rights enshrined in the ECHR. Had this been their intention, the rejection of the 1961 Proposal would not have constituted adequate means to

${ }^{1193}$ In strict pursuance of Reichel's version of this argument, such a right would be identical with the non-adopted 1961 Proposal, containing a right to seek and enjoy asylum from persecution as well as a prohibition of refoulement to persecution. See text accompanying note 1168 above. 
express it. ${ }^{194}$ Given its flawed premise and, additionally, the methodological inappropriateness of the historical data used to underpin this argument, Reichel's and Maaßen's critique loses its decisive trump.

Ad 5): As we have seen, both critics have involved the customary law of state responsibility in their reasoning. They state no reason for doing so, and such a reason is not immediately evident. State responsibility does not offer norms of a higher dignity impeding an extensive interpretation of Article 3 ECHR. In fact, state responsibility may be considered relevant in an indirect manner. The critics may intend to show that a certain interpretation 'fits well' or 'does not fit' with the grid or norms in the area of state responsibility. In short, they want to prove that their interpretation is more consistent with that grid: it reduces complexity without producing additional complexity elsewhere in the system. What they suggest is the construction of an analogy between human rights law and the law of state responsibility.

The problem is twofold. First, the allocation of responsibility in the tripartite conflict with different classes of participants at stake under Article 3 ECHR (the bearers of interest being the returning state, the receiving state and the individual, the latter not possessing the same legal personality as the two former) is qualitatively different from the existing rules on state responsibility. The latter are seized with inter-state relations and deal with human rights violations only in an indirect manner. ${ }^{1195} \mathrm{In}$ this regard, human rights law and the law of state responsibility are simply not sufficiently comparable to allow for ex analogia reasoning.

Second, the law of state responsibility is sufficiently open to allow for a universalist as well as a particularist analogy. We recall that both critics come to diametrically opposed conclusions: while Reichel finds that an extensive interpretation of Article $3 \mathrm{ECHR}$ is consistent with the rules on state responsibility, Maaßen suggests the opposite. Obviously, this field of international law only reproduces the choice encountered when interpreting Article 3 ECHR.

1194 In line with Art. 31 (3) (a) VTC, one may think of an 'agreement between the parties regarding the interpretation of the treaty or the application of its provisions' as an adequate means.

1195 Compare Art. 19 (3) (c) ILC Draft declaring certain violations of human rights to be international crimes. It is quite indicative that this draft provision has attracted a fair amount of criticism so far. 


\section{CHAPTER 10}

The causal linkage between the anticipated human rights violation by a third state and the responsibility of the removing state can be elucidated further by making recourse to the ILC Draft Articles on International Responsibility of States, to some extent reflective of customary international law. According to the Draft Articles, state responsibility flows from an internationally wrongful act.

There is an internationally wrongful act of a State when:

(a) Conduct consisting of an action or omission is attributable to the State under international law; and

(b) That conduct constitutes a breach of an international obligation of the State. ${ }^{1196}$

The action of removal is decided on and executed by agents of the removing state and consequently attributable to it. ${ }^{1197}$ While removal of an alien as such is clearly permitted by international law, removal in a manner or under circumstances violating the ECHR is not. A state not taking the latter restrictions into account will attract responsibility under international law for such a removal.

Determining the content of 'to subject' and determining the limits of attribution offer identical interpretative dilemmata. Drawing analogies between human rights law and the law of state responsibility amounts to a mere replication of the problem.

Concluding on the context of Article $3 \mathrm{ECHR}$, we may state that the reference to Article 1 ECHR remains the only constructive contribution to the interpretative problem discussed here. All the other sets of data provide for circular arguments or suffer from logical flaws. As remarked earlier, the predominantly negative obligation in Article 3 ECHR is now complemented with a predominantly positive obligation in Article 1 ECHR. This suggests that a contextual interpretation supports the outcome arrived at by the Court.

Moving on to a teleological interpretation, we find ourselves confronted with the very abstract goal of promoting human rights. In their most pertinent and still rather hazy recital of the preamble, the Contracting Parties express their resolve 'to take the first steps for the

\footnotetext{
1196 ILC Draft Articles on International Responsibility of States, YILC 1980 Vol. II (Part 2), pp. 30-4, Art. 2.

1197 Ibid, Art. 5.
} 
collective enforcement of certain of the Rights stated in the Universal Declaration'. ${ }^{1198}$ This aim propels us back to the very conflict between universalists and particularists on how to best promote human rights, expounded at some length above. It largely restores the complexity of the original political conflict and leaves the interpreter with the stalemate of an indeterminate outcome. The Court drew once more on an oft-invoked interpretative rule, stipulating that the Convention rights must be interpreted in such a way as to make them practical and effective. ${ }^{1199}$ At first glance, this would suggest working in favour of the individual and advancing the universalist position. However, a second look reveals that the principle of effectiveness cannot shift the indeterminate setting. What is to be regarded as effective is equally vague and ambiguous as how to best promote a telos. After all, invoking this principle cannot alter the indeterminate outcome of a teleological interpretation.

Now, at the end of the second stage, we must combine the results of the contextual and the teleological interpretation. True enough, the former favours a universalist interpretation. Nonetheless, the indeterminacy of the latter begs questions. Admittedly, this indeterminacy is most useful for the partisan practitioner. The protection seeker's counsel may argue for a universalist reading of the telos, thus being able to produce a determinate outcome in the second stage. This allows the counsel to bar recourse to the third stage ${ }^{1200}$ and declare the process of interpretation to be finished. The government would typically do the opposite, arguing that results yielded by the contextual and the teleological interpretation contradict each other and lead to an ambiguous outcome in the sense of Article 32 VTC. Theoretically, it is not immediately evident how the indeterminacy of the teleological interpretation should be handled. Two options are conceivable. Either teleological indeterminacy is a neutral factor when combining results of the contextual and teleological interpretations-suggesting that the universalist result of contextual interpretation shall prevail-or the stated teleological indeterminacy alone is sufficient to make the result of the second stage ambiguous, regardless of the clarity attained by the contextual interpretation. The question would not arise, if the contextual and teleological interpretations were found in separate, hierarchically

\footnotetext{
1198 Fifth recital of the preamble of the ECHR.

1199 See Soering, para. 87 with further references to earlier case law.

1200 Save for the purpose of confirming the universalist result, in line with Art. 32 VTC.
} 


\section{CHAPTER 10}

ordered stages. Had this been the case, the clarity attained in the contextual interpretation would make any dealings with the telos superfluous.

However, we maintain that the first option must be chosen. To opt for the second would endow an indeterminate outcome in one of the two interpretations with the same weight as a clear-cut contradictory outcome, where both interpretations would lead to diametrically opposed results. It would imply a procedural advantage to the particularist position. When combining the two interpretations under the second stage, indeterminate outcomes must be treated as neutral entities, having a zero value in the final count of universalist and particularist arguments. This is in line with the rationale of the rule of interpretation enshrined in Article 31 VTC: to provide for a hierarchically structured increase of complexity, precisely to the extent needed for reduction. The second option defies the logic of executing interpretation in three distinct stages. In that sense, interpretation is not about the eradication of reasonable doubts, but rather about the establishment of justificatory dominance. As shown above, Article 1 ECHR provides for an abundance of data justifying a universalist outcome.

With this conclusion, there is no need to move on to the third stage. At any rate, this stage would have largely reproduced the universalistparticularist divide. A consultation of the travaux leads to ambiguous results, as indicated in the discussion of the doctrinal critique above. The abortive 1961 Proposal on the inclusion of a right to asylum would stand against the omission of the territorial limitation of the Convention's scope. ${ }^{1201}$

Apart from the travaux, other data could be adduced. Most important is probably the emerging consensus on a universalist reading of Article 3 ECHR, as it manifests itself in the discussions in the Council of the European Union. ${ }^{1202}$ Based on a Danish initiative, various documents on subsidiary protection have been circulated since 1997, and the case-law of the European Court of Human Rights on cases involving extraterritorial threats holds a prominent place in them. In 1999, the Austrian Presidency

\footnotetext{
1201 See chapter 10.1.1.3 above.

1202 As for now, the domestic laws of some Contracting Parties feature protection categories that are inspired by a universalist interpretation of Art. 3 ECHR. Suffice it here to name Section 53 (4) of the German Aliens Act and Chapter 3 Section 3 (1) of the Swedish Aliens Act.
} 
summarised the state of discussions as follows: 'Of the subsidiary protection instruments existing in the European Union, Article 3 of the European Convention on Human Rights is particularly important'. ${ }^{1203}$ The note by the presidency goes on to discuss the impact of the Court's case law, of which 'use should be [...] made [...] in formulating policy for common legislation, although this involves judgements in individual cases, which may differ according to circumstances'. ${ }^{1204}$ If these discussions will indeed produce a legislative measure transforming the case law of the Court into community law, a universalist reading would have won express support by a large part of the Contracting Parties to the ECHR. ${ }^{1205}$

Assuming for a moment that it would be warranted to move on to the third stage under Article 32 VTC, this would add no further determinacy. To conclude, the universalist conclusion derived in the second stage still stands: Article 3 ECHR must be construed as embracing extraterritorial protection.

\subsubsection{Article 7 ICCPR}

In principle, the reasoning developed above is applicable to Article 7 ICCPR as well. ${ }^{1206}$ Above, we had identified five sets of data as relevant for the interpretation of Article 3 ECHR. Mutatis mutandis, four of them are relevant for the interpretation of the ICCPR:

1. Article 2 (1) ICCPR, obliging Contracting Parties to 'respect and to ensure to all persons within its territory and subject to its jurisdiction' the rights recognized in the Covenant, inter alia Article 7 ICCPR;

2. the state right to control the entry of non-citizens;

${ }^{1203}$ Council of the European Union, Note from the Presidency to the Asylum Working Party, Subsidiary Protection, 23 February 1999, Doc. No. 6246/99 ASILE 7, para. 4.

${ }^{1204}$ Ibid., para. 6 (a).

${ }^{1205}$ However, as the Union is not congruent with the group of State Parties to the ECHR, such an instrument would not constitute part of the context as alluded to in Art. 32 (3) VTC.

1206 The Human Rights Committee opines that Art. 7 ICCPR prohibits extradition, expulsion and refoulement to a country disregarding the content of this provision. See General Comment 20/44, 3 April 1993, para. 9. 


\section{CHAPTER 10}

3. the absence of an explicit right to asylum in the Convention; and

4. the law of state responsibility.

There is no provision corresponding to Article 5 (1) (f) ECHR in the ICCPR. The pivotal factor is Article 2 (1) ICCPR, which provides the contextual element tilting interpretation in favour of a universalist reading. Therefore, even Article 7 ICCPR must be read to imply a right to extraterritorial protection. This reading has been endorsed by the Human Rights Committee in a number of cases related to Article 7 ICCPR. ${ }^{1207}$

\subsection{Access to Territory}

The second question was whether an individual entitlement to migrate in order to seek extraterritorial protection exists. An interpretation based on the terms of Article 12 (2) ICCPR and Article 2 of the Fourth Protocol could not clarify this issue.

Drawing on contextual and teleological interpretations, two lines of argument shall be pursued. First, Article 12 ICCPR shall be put in the context of inter-state norms regulating migration. This approach is in line with Article 31 (3) (c) VTC, stating that any relevant rules of international law applicable in the relations between the parties shall be taken into account together with the context. Second, Article 3 ECHR and Article 7 ICCPR shall be interpreted in the context of other provisions in each of the respective treaties. The latter provisions form part of the context according to Article 31 (2) VTC. Moreover, both provisions shall be interpreted teleologically as well.

\subsubsection{The Right to Leave and the Right to Entry}

We had been seized with the question whether or not Article 12 ICCPR implies a correlative right to enter another country. Hitherto, this question has not been dealt with in the case law of the Human Rights

\footnotetext{
1207 Human Rights Committee, Kindler vs. Canada, No. 470/1991, UN Doc. No. CCPR/C/48/D/470/1991; Human Rights Committee, Ng vs. Canada, No. 469/1991, UN Doc. No. CCPR/C/49/D/469/1991; Human Rights Committee, Cox vs. Canada, No. 486/1991, UN Doc. No. CCPR/C/45/D/468/1991.
} 
Committee, and doctrinal discussion of the issue remains rather limited. In the following, we shall first present a universalist reading affirming such a correlative right and, second, complement it with a particularist reading, denying its existence.

\subsubsection{A Universalist Reading}

It should be noted that the right to leave can be interpreted in two ways. It can be read as solely enshrining an entitlement vis-à-vis the country of origin. Or it can be read to contain an additional entitlement vis-à-vis all states. In this section, we shall argue for the existence of the latter entitlement from a particularist perspective.

Indeed, the right to leave one's country would be nullified in a situation where no other state was prepared to receive the individual making use of this right. The ideal to be realised by the right to leave and the right to return is the free movement of persons. Since these rights were conceived, the actual problem has shifted. The number of states preventing their citizens from leaving or prohibiting their return is clearly decreasing. ${ }^{1208}$ Instead, free movement is hampered by a parallel emergence of immigration restrictions. ${ }^{1209}$

The wording of Article 12 ICCPR does not restrict it being a claim only vis-à-vis the country of origin. We shall now introduce a contextual argument, which rests upon an analogy between the inter-state right to return aliens to their country of origin and the human right to leave any country, including one's own.

How is the inter-state right structured? As a corollary flowing from their territorial and personal supremacy, States have a qualified right to expel aliens from their territory. In order for this right to become effective, another State has to receive the person expelled. It is largely uncontested that this obligation to receive rests upon the State of which

\footnotetext{
1208 K. Hailbronner, Rückübernabme eigener und fremder Staatsangeböriger. Völkerrechtliche Verpflichtungen der Staaten (1996, C. F. Müller Verlag, Heidelberg), p. 6.

1209 See note 226 above.
} 


\section{CHAPTER 10}

the expelled person is a citizen. ${ }^{1210}$ Thus, the right of a State to remove non-citizens from its territory has been extrapolated to produce a duty to receive by the country of origin. This correlate is regarded as a norm of customary international law ${ }^{1211}$ although single countries of origin deny readmission to citizens not returning voluntarily. Recurring to the standards of interpretation enshrined in the Vienna Convention, it can be stated that the customary law norms governing inter-state relations are applicable in the relations between all State Parties to the ICCPR. Following Article 31 (3) (c) VTC, they form part of the context of Article 12 ICCPR. As such, they must be taken into account when interpreting this right.

Let us grant for a moment that the requirements of a sufficiently consistent practice ${ }^{1212}$ and the requirement of opinio juris ${ }^{1213}$ are fulfilled. This would prove that inter-State international law accepts the deduction of a correlative duty from a right. It follows that opinio juris embraces the logic of correlates. If the same argumentative technique of constructing a duty as a correlate to a right is applied in the field of human rights, the right to leave produces a duty to admit. In order for the former to be effective, one has to construct the latter. This line of argument entails an all-or-nothing outcome. Either it is accepted that the logic of correlates is part of customary international law, thus validating both an inter-state duty to readmit nationals and a human right to immigration, or it is

1210 The non-binding Cairo Programme of Action described this obligation as follows: 'Governments of countries of origin of undocumented migrants and persons whose asylum claims have been rejected have the responsibility to accept the return and reintegration of those persons, and should not penalize such persons on their return'. Programme of Action, International Conference on Population and Development, Cairo, 5-13 September 1994, UN Doc No. A/CONF.171/13, 18 October 1994, para. 10.20. Further on the obligation to receive, Hailbronner, 1996, p. 36; and Plender, 1988, p. 460.

1211 It is hard, if not impossible, to assess the efficiency of return in practice. Comprehensive statistics are lacking.

1212 Apart from those states outrightly denying readmission to non-voluntary returnees, others obstruct return by administrative measures. By way of example, the returnee is declared not to be a citizen of the requested state, or return is denied due to lacking travel or identity documents. See G. Noll, 'Unsucessful Asylum Seekers-The Problem of Return', 37 International Migration 267 (1999), pp. 274-5.

1213 See the Cairo Programme of Action, note 1210 above. In a number of bilateral readmission agreements regulating the return of nationals to their country of origin, the right to return is merely reaffirmed. See note 1028 above. 
denied that customary international law embraces the logic of correlates. In that case, a human right to immigration would fall, bringing with itself in the inter-state duty to readmit nationals.

It is quite clear from the analysis of the travaux préparatoires to the ICCPR that states intended to preserve their control over the composition of their populations. ${ }^{1214}$ Now, accepting the logic of correlates as part of international law seems to produce a puzzling result. How can a state right to control the composition of its population coexist with an individual right to entry? If the right to entry is understood as a long-term or even permanent change of settlement, those rights indeed conflict. However, if one frames the concept of entry as a temporary one, they go along very well with each other. Drawing on the latter understanding, the individual's right to entry is merely a right to make contact with the territory of a state, pending a decision of the entered state whether to accept or to reject the entrant. This understanding would limit the right to entry to the transgression of physical borders, while admitting that the transgression of administrative borders remains a state prerogative. It also endows the inter-state duty to readmit nationals with additional functionality. After all, the temporary nature of a stay can only be enforced by efficient return, which is preconditioned on a duty to readmit. Thus, the logic of correlates augments coherence within the corpus of norms related to migration.

Marginally, one might wish to note that such a reading shows a striking correspondence to the Kantian 'right to visit'. ${ }^{1215}$ It must be underscored, however, that the legal right to entry is deduced not from philosophical premises, but from legal ones. ${ }^{1216}$ This interpretation manages to reconcile both individual and state rights without postulating artificial normative hierarchies.

\footnotetext{
1214 Hailbronner, 1996, p. 11.

1215 See chapter 2.2 above.

1216 Therefore, Grahl-Madsen, Melander and Ring miss the point when they conclude that '[1] ogic does not entitle us to infer a right of entry in countries other than one's own, since the right of States to control entry into their respective territories is a jealously guarded privilege'. Indeed, the philosopher's logic may not, but the lawmaker's does. Moreover, as indicated above, the lawmaker's logic is careful enough to leave right to control entry untouched in the long term. A. Grahl Madsen, G. Melander, and R. Ring, 'Article 13', in G. Alfredsson and A. Eide (eds), The Universal Declaration of Human Rights. A Common Standard of Acbievement (1999, Martinus Nijhoff Publishers, The Hague), p. 276.
} 


\section{CHAPTER 10}

The contextual interpretation expounded above must be complemented by a teleological interpretation. This poses problems very similar to those encountered when interpreting Article 3 ECHR. The telos of human rights protection is broad and abstract; this brings us back to the original conflict between universalists and particularists. The ideal of free movement is subject to the same divide: who is to tell whether an all-out slashing of limitations or a gradual process of controlled deregulation is the best device to achieve it?

Let us sum up on the universalist line of reasoning. The second stage affirmed the existence of a right to temporary immigration under the contextual interpretation and yielded a neutral, i.e. indeterminate, outcome under the teleological interpretation. Cumulating both sets of data produces the following result: Article 12 ICCPR must be read to imply a temporary right to make contact with the territory of states other than one's home country. Interpretatio cessat in claris-there is no need to proceed to the third stage.

\subsubsection{A Particularist Reading}

\subsection{Complementing the Second Stage}

From the preceding section, it emerges that the universalist position is based on a contextual argument, allowing it to produce a determinate conclusion in the second stage. However, there is another contextual argument, suggesting a different outcome.

Earlier, it has been acknowledged that states possess a right to control the composition of their population. A widespread tool to exercise this right to control is the imposition of visa requirements. The number of states using this tool and the number of nationalities subjected to such requirements is on the rise. In the EU, all Member States are duty-bound to impose visa requirements along the Visa Regulation. ${ }^{1217}$ In the U.S., visa requirements have been used throughout the whole century, and enforced extraterritorially by placing U.S. immigration agents at points of embarkation in third countries. ${ }^{1218}$ Although visa requirements represent a barrier to free movement and can be perceived as politically undesirable, it

1217 See chapter 5.1.1.1 above.

1218 See generally Christian, 1999. 
has not been claimed that they are illegal under international law. There is a widespread practice of states in all parts of the world, and there is also an opinio juris accepting their general conformity with international law. ${ }^{1219}$ Thus, we may state that a customary law norm exists allowing states to use visa requirements as a tool of migration control. Following Article 31 (3) (c) VTC, this norm forms part of the context of Article 12 ICCPR.

The rationale of visa requirements is to inhibit a would-be emigrant from setting out on a journey to a country unwilling to receive her. If visa requirements are legal, it must also be considered legal to inhibit nonnationals from having territorial contact with a potential destination country. The state right to deny entry would not only relate to the administrative boundary, but the territorial boundary as well. This state right cannot be reconciled with a temporary right to entry held by the individual, as developed earlier. Its existence confirms that the ICCPR simply does not guarantee a general right to entry into the territory of the Contracting Parties. ${ }^{1220}$

With two powerful contextual arguments standing against each other, contextual interpretation cannot deliver a determinate outcome. Recalling the indeterminacy produced by the teleological interpretation, the second stage must be said to produce an ambiguous result. Therefore, it is mandatory to proceed to the third stage.

\subsection{The Third Stage}

The particularist position is further reinforced by arguments becoming accessible in the third stage. The travaux of the ICCPR offer ample proof that many of the Contracting Parties had an attitude favourable to limiting freedom of movement. In a 1950 meeting of the Human Rights Committee, the British delegation had requested the outright deletion of the relevant draft article. This proposal was rejected by nine votes to three, with two delegations abstaining from the vote. ${ }^{1221}$ The travaux also show that the wording of Article 13 UDHR was perceived as too liberal

\footnotetext{
1219 For an overview of practices, see e.g. Commissioner of the CBSS, Conditions for Travel Across the National Borders of the CBSS Member States, 10 May 1999, pp. 20-36.

1220 M. Nowak, UNO-Pakt über bürgerliche und politische Rechte und Fakultativprotokoll. CCPR-Kommentar (1989, N.P. Engel Verlag, Kehl am Rhein), p. 229.

1221 Nowak, 1989, p. 209, quoting E/CN.4/SR.151, para. 44.
} 


\section{CHAPTER 10}

in some respects. ${ }^{1222}$ By consequence, the Human Rights Committee agreed on the deletion of a general prohibition of exile as well as a number of qualifications of the freedom of movement. ${ }^{1223}$ Finally, the Human Rights Committee dropped the introduction of a right to asylum as early as $1950 .^{1224}$

In the third part, focus has shifted from the letter of the law to the intention of the legislator. This intention is clearly not in favour of an extensive interpretation of Article 12 ICCPR. Therefore, the particularist has improved her position, arguing that the aggregate conclusion must be that this provision does not contain an implied right to entry, be it temporary or not.

\subsubsection{Conclusion}

The discussion on Article 12 ICCPR provided a telling illustration of the interplay between material content and interpretative rules. In the second stage, the universalist argument appears to be more precisely formulated than the particularist counter-argument. As the gap between the two arguments is too wide to be bridged, there are faint chances for the construction of further universalist arguments consuming the visa argument. Therefore, the universalist can hardly argue that the interpretative conflict can be solved in an unambiguous or non-obscure manner in the second stage. Thus, what the particularist needs in the second stage is not an objectively better argument, capable of defeating the universalist stance, but one strong enough to produce indeterminacy. The visa argument is sufficiently strong in this regard, and the third stage is activated, allowing the particularist to access further arguments for her cause.

Does this mean that the aggregate outcome of the interpretative operation is in favour of the particularist? Having gone through all three stages according to the prescriptions of the Vienna Convention, we are

\footnotetext{
1222 Nowak, 1989, p. 210.

${ }^{1223}$ Firstly, internal freedom of movement was limited to those lawfully present in the territory of a Contracting Party. Secondly, a derogation option was introduced, covering internal freedom of movement as well as the right to leave. Thirdly, the ICCPR provision merely prohibits only those deprivations of the right to return which are arbitrary.

1224 Nowak, 1989, p. 210.
} 
left with an array of contradicting arguments. The Vienna Convention does not provide any help for the process of weighing these arguments against each other. Thus, the interpretation of Article 12 ICCPR ends with an indeterminate result and is ultimately open to the decision-makers preferences.

\subsubsection{Explicit Prohibitions of Refoulement}

\subsubsection{Article 33 GC}

\subsection{The Second and Third Stage in the Light of Doctrinal Debate}

Determining whether Article 33 GC applies to rejection at the border has been a standard topic for doctrinal writers ever since the inception of the 1951 Refugee Convention. Naturally, it does not evade the dichotomy between universalism and particularism. Inclusive readings affirm the applicability of Article 33 GC to border claims by referring to the logic of the law, usually drawing on its object and purpose, or pointing to 'absurd results' flowing from non-applicability. ${ }^{1225}$ On the other hand, exclusionary readings largely rely on a reconstruction of the legislator's will, which is said to underpin the non-applicability of Article 33 to border claims. These reconstructions draw on the travaux and on the absence of a Convention provision regulating the admission of refugees. ${ }^{1226}$ Given the richness of doctrinal thought, there is no need to craft further substantial arguments. However, not all of the arguments advanced in doctrine are constructed in a manner compatible with the Vienna Convention. In the following discussion of selected arguments, we shall use the Vienna Convention as a watershed for distinguishing arguable approaches from non-arguable ones.

In older literature, we find rather clear-cut statements with cursory motivations. The first exclusionary reading was advanced by Robinson in

\footnotetext{
${ }^{1225}$ See, e.g. M. Pellonpää, Expulsion in International Law. A Study in International Aliens Law and Human Rights with Special Reference to Finland (1984, Suomalainen Tiedeakatemia, Helsinki), p. 313. For an overview of inclusionary positions in doctrinal thought, see Davy, 1996, p. 94, footnote 8.

1226 For an overview of exclusionary positions in doctrinal thought, see Davy, 1996, p. 93, footnote 3 , and p. 94, footnote 7 .
} 


\section{CHAPTER 10}

1953. He denies that Article 33 GC applies to refugees seeking entrance into the territory of a potential host state: '[I]f a refugee has succeeded in eluding the frontier guards, he is safe; if he has not, it is his hard luck' ${ }^{1227}$ In a footnote, Robinson claims that the drafters did not intend to regulate admission by Article 33. ${ }^{1228}$ Later on, a number of authors have based their exclusionary reading on this argument. ${ }^{1229}$

Recurring to the Vienna Convention, we have to state that Robinson leaps to the travaux without devoting any interest to the wording, context or telos of Article 33 GC. Quite clearly, this negligence strikes back at the viability of his results. We would like to add another reflection. Interestingly, Robinson deplores that his interpretation of Article $33 \mathrm{GC}$ falls short of the protection provided in Article 3 (3) of the 1933 Convention, which provided that Contracting States undertake in any case not to refuse entry to refugees at the frontiers of their country of origin'. ${ }^{1230}$ Nonetheless, he fails to see an interpretative idiosyncrasy flowing from this observation. After all, the High Contracting Parties to the 1951 Refugee Convention considered

that it is desirable to revise and consolidate previous international agreements relating to the status of refugees and to extend the scope of and protection accorded by such instruments by means of a new agreement ${ }^{1231}$

\footnotetext{
1227 N. Robinson, Convention Relating to the Status of Refugees. Its History, Contents and Interpretation, 1997 ed. (1953, UNHCR, Geneva), p. 138.

1228 Ibid., at 139, footnote 275.

1229 A. Zimmermann, Das neue Grundrecht auf Asyl (1994, Springer, Berlin), p. 74; Maaßen, 1997, p. 78.

1230 Convention relating to the International Status of Refugees, 28 October 1933, 159 LNTS 199. See also Robinson, 1953, p. 139. In his literal interpretation of the term 'refouler', Maaßen also takes note of this provision (Maaßen, 1997, p. 62). By pointing to the fact that only eight states had ratified the 1933 Convention, he attempts to disqualify its importance. In the light of the teleological interpretation presented here, his counterargument is irrelevant. What counts is the fact that the Contracting Parties to the 1951 Refugee Convention explicitly named the 1933 Convention in Art. 1 A. (1) GC and that they expressed their wish to 'extend the scope of and protection accorded by' the 1933 Convention in the preamble.

$12312^{\text {thd }}$ recital, preamble of the 1951 Refugee Convention.
} 
An exclusionary reading is at odds with this telos, as the 1951 Refugee Convention would offer a territorially more restricted scope of protection than the 1933 Convention.

Goodwin-Gill takes a moderate position, granting that Article 33 GC may not have been applicable to non-rejection at the border from the outset. However, following his argument, an extension of the provision's scope had taken place through later state practice. ${ }^{1232}$ Goodwin-Gill does not refer to the Vienna Convention. His argument of extension through state practice may be subsumed under Article 31 (3) (b) VTC, but his sparse examples fail to show the existence of 'any subsequent practice in the application of the treaty which establishes the agreement of the parties regarding its interpretation'.

While the earlier discussions went directly for what was considered a relevant argument, more recent contributions explicitly relate to the Vienna Convention. An elaborate inclusionary reading has been proposed by Kälin, who operates both substantial and methodological arguments. ${ }^{1233}$ Countering other authors' exclusive readings based on the travaux, Kälin rightly asserts that the Vienna Convention inhibits recourse to the latter, where a clear result has been derived from the norm's context and telos. ${ }^{1234}$ While the travaux may very well reveal the drafters' unwillingness to regulate admission, this is irrelevant for the purpose of interpretation. Kälin himself states rightly that the wording of Article $33 \mathrm{GC}$ is open to an inclusionary reading. ${ }^{1235}$ In his view, a clear result can be derived from a teleological interpretation. Following his view, it is the aim of Article 33 GC to inhibit that a refugee, who has managed to evade a country of persecution, is returned to it. ${ }^{1236}$

His reading is opposed by Reichel, who manages to transform the travaux argument on the non-regulation of admission into a contextual argument, thereby evading Kälin's methodological critique. ${ }^{1237}$ Reichel

\footnotetext{
${ }^{1232}$ Goodwin-Gill, 1996, pp. 121-4, at 123.

${ }^{1233}$ Kälin, 1982, pp. 105-10.

1234 'Während eine an der Entstehungsgeschichte orientierte Auslegungsmethode zu einem negativem Ergebnis kommt, führt eine grammatikalische und teleologische Interpretation zu einem positiven Ergebnis. Welcher Auslegungsmethode in einem solchen Fall der Vorzug zu geben ist, lässt sich der Wiener Vertragsrechtkonvention (VK) entnehmen [footnote omitted, GN]'. Kälin, 1982, pp. 108, 109.

1235 Kälin, 1982, p. 105.

1236 Kälin, 1982, p. 107.

1237 Reichel, 1987, pp. 39-42.
} 
refers to the following passage in the Final Act of the 1951 Refugee Convention:

\begin{abstract}
The Conference
$[\ldots]$

recommends that Governments continue to receive refugees in their territories and that they act in concert in a true spirit of international co-operation in order that these refugees may find asylum and the possibility of resettlement. ${ }^{1238}$
\end{abstract}

How does this passage affect the interpretation of Article 33 GC? Reichel is correct in qualifying this dictum as a part of the norm.'s context. ${ }^{1239}$ Subsequently, he argues that it would lack meaning to recommend continued reception of refugees to governments, if Article $33 \mathrm{GC}$ obliged them not to reject refugees at the border. ${ }^{1240}$ However, this argument $\mathrm{e}$ contrario is unconvincing, as 'reception' remains a wider concept than non-rejection at the frontier. The meaning of 'reception' ranges from nonobstruction of physical entry to the meting out of a specific personal status. Given this incongruity, it is logically untenable to take the quoted passage as an indicative for the interpretation of Article 33 GC by the Contracting Parties. Compared to earlier proponents of an exclusive reading, Reichel barters a methodological error for a logical one.

An ambitious, but methodologically flawed, attempt to clear our thoughts on Article 33 GC has been put forward by Maaßen. Drawing mainly on the by now well-known argument of a missing intent to regulate admission, he concludes that this provision does not encompass rejection at the border. ${ }^{1241}$ The Vienna Convention is invoked in support of Maaßen's assertion. But his understanding of the General rule of interpretation in Article 31 of the latter instrument builds entirely on the subjective approach focusing on state intent. Obviously, in the present case, such an understanding promotes an exclusionary reading of Article 33 GC. Had Maaßen followed Articles 31 and 32 VTC strictly, he would have started with a literal interpretation, concluded that the wording was

\footnotetext{
${ }^{1238}$ Final Act of the United Nations Conference of Plenipotentiaries on the Status of Refugees and Stateless Persons, 189 UNTS 37, 28 July 1951, IV, D.

1239 Art. 31 (2) (a) VTC.

1240 Reichel, 1987, pp. 40 and 41.

1241 Maaßen, 1997, pp. 55-80.
} 
not sufficiently clear, and directly proceeded to a contextual and teleological interpretation. Instead, he attempts to identify the historical and present intent of the Contracting States as part and parcel of a literal interpretation. To this end, he drat.s on the travaux. There is no support whatsoever in the Vienna Convention to supercharge the ordinary meaning of a term with contents derived from the drafting process. Maaßens' method turns a blind eye to the subsidiary character of the travaux, which are to be consulted if and only if the 'single combined operation'1242 of literal, contextual and teleological interpretation has not produced a sufficiently clear or reasonable result. ${ }^{1243}$ Even if one accepts the contested state intent approach ${ }^{1244}$, the latter must not serve as an excuse to circumvent Article 32 VTC. While Maaßen observes the risk of contradiction between the subjective approach and the Vienna Convention $^{1245}$, he disregards that very risk in his actual interpretation. ${ }^{1246}$

Although Maaßen fails to realise it, his contribution demarcates a change in the discussion's focus. Given the richness of accumulated arguments, the battle on the proper interpretation of Article 33 GC can no longer be won on a substantial level. The decisive arguments are those relating to the interpretation of interpretative rules. Here, we experience a shift from the legal-technical to the qualitative level. The Vienna Convention is not a monolith, but-like any other body of norms-is open to interpretation. Although it pre-establishes the precarious balance between the letter of the law and the intent of the legislator, there is enough room for a versed interpreter to promote one of these parameters at the cost of the other. ${ }^{1247}$ Both Reichel and Maaßen have realised that substantial arguments may be precluded by the Vienna Convention if they are not cloaked in proper form. Maaßen goes a step further and attempts to secure a better substantial outcome by reinterpreting the interpretative rules contained in the Vienna Convention. In short, this method is about producing substance through form. Although he fails in this effort, it is not inconceivable that future discussants manage to

\footnotetext{
1242 YILC 1966 II, p. 219.

1243 Compare the wording of Art. 32 VTC.

1244 For a discussion, see K. Ipsen, Völkerrecht (1990, C.H. Beck, München), pp. 7-14 and 121-2.

1245 Maaßen, 1997, p. 61.

1246 Maaßen, 1997, p. 64.

1247 Bernhardt, 1992, p. 1418.
} 


\section{CHAPTER 10}

construct a tenable exclusionary reading by exploiting the idiosyncrasies of the Vienna Convention. Maaßen's attempt is, however, doomed because it lacks the necessary sophistication.

Recently, Davy has made what could be termed the most carefully argued and exhaustive contribution to this debate hitherto. ${ }^{1248}$ Simultaneously, she is most orthodox in her handling of the Vienna Convention, which ultimately secures her success. Davy rejects an exclusionary reading for three reasons. ${ }^{1249}$ First, the drafting history of the Convention does not offer unambiguous support for the contention that rejection at the border is outside the scope of Article $33 \mathrm{GC}$. The oftquoted statements by delegates in support of an exclusionary reading have been superseded later in the drafting process. To wit, the exceptions in Article 33 (2) GC were included, meeting the demands for a limitation of the prohibition of refoulement. Moreover, the expression 'in any manner whatsoever' was included in the wording of Article 33 (1) GC, supporting an inclusionary interpretation of this norm. Finally, delegations also complemented the English term 'return' with the French term 'refouler'. Davy presents an interesting analysis of the latter amendment. She holds that the drafters intended to exclude measures taken at the border by inserting the term 'refouler' into the norm. However, this term relates also-and, in some cases, primarily-to measures taken at the border. In francophone asylum law and practice, 'refouler' covered non-admittance at the border. ${ }^{1250}$ The same applies for the international refugee law of the 1930s, which was another point of reference for the drafters. ${ }^{1251}$ And, most importantly, the ordinary meaning of 'refouler' also includes rejection at the frontier. ${ }^{1252}$ According to Davy, the conclusion is inevitable that a linguistic mistake has been committed in the drafting of Article 33 (1) GC. ${ }^{1253}$

\footnotetext{
1248 Davy, 1996, pp. 93-123.

1249 Davy, 1996, p. 95.

1250 Davy, 1996, pp. 101-3.

1251 Davy, 1996, p. 104.

1252 Davy, 1996, pp. 104-5.

1253 'Das Wort "refouler" verweist jedoch auch (und manchmal sogar vorrangig) auf Massnahmen an der Grenze. Bei der Abfassung des Art $33 \mathrm{Z} 1$ ist also-diese Schlussfolgerung scheint unausweichlich-ein sprachlicher Fehler unterlaufen.' Davy, 1996, p. 105.
} 
Thus having defeated exclusionary readings based on the legislative history, Davy proceeds to a reinterpretation of Article 33 (1) GC along the lines of the Vienna Convention. She reverts to the ordinary meaning of 'refouler', which includes rejection at the frontier, and complements the linguistic interpretation by a contextual one. Among the contextual data, she identifies Article 33 (2) GC and Article 31 (1) GC as particularly important.

Article 33 (2) enshrines exceptions to the prohibition of refoulement and is worded as follows:

The benefit of the present provision may not, however, be claimed by a refugee whom there are reasonable grounds for regarding as a danger to the security of the country in which he is, or who, having been convicted by a final judgment of a particularly serious crime, constitutes a danger to the community of that country.

The expression 'as a danger to the security of the country in which he is' may be taken to support an exclusionary reading, ruling out the applicability of the whole provision, including its first paragraph, to rejection at the border. However, as Davy argues, two reasons militate against such a conclusion. Firstly, Article 33 (2) GC specifies a sub-group, which fulfils the prerequisites of Article 33 (1) GC, but which shall be excluded from its benefits. Thus, the group of persons alluded to in Article 33 (2) GC is not identical with the one alluded to in Article 33 (1) GC. Therefore, the qualifications of the former cannot be analogously transferred to the latter. Secondly, Davy points out that border controls usually take place on state territory, which means that a person waiting at the border is within the scope of Article 33 (2) GC. Summing up, Davy opines that a mere recourse to Article 33 (2) GC cannot deliver a determinate outcome. 


\section{CHAPTER 10}

She proceeds to Article 31 (1) GC, which exempts refugees from penalties on account of illegal entry or presence ${ }^{1254}$, and tracks the legislative history of this provision. She lays bare the hierarchy of interests inherent in this provision, which accords the interests of the refugee a position prior to those of the state. In the next step, she concludes that it would be an evaluative contradiction to exempt refugees entering illegally from penalties, while insisting on an unconditional state right to reject refugees at the border. On the contrary: if the Convention compels Contracting States to refrain from penalising the violation of entry regulations by refugees, it must be concluded a fortiori that the Convention does not allow that the observance of the same regulations is enforced ex ante by the means of refoulement. ${ }^{1255}$

Davy's contextual argument is much more focused and precise than earlier advanced arguments on the contradiction between the telos of the Convention and the non-applicability of Article 33 (1) GC to rejection at the border. ${ }^{1256}$ As her inclusionary reading is derived from a rigorous application of the Vienna Convention, it has to be unreservedly endorsed. Her interpretation produces a clear and unambigucus result already in the second stage. She never resorts to a telenlogical interpretation in the narrow sense, but draws on expressions of the telos in the norm context instead. Summing up, we may state that Davy fully exploits the strategic advantage offered by the Vienna Convention, ailowing the letter and logic of the law to overrule other manifestations of the legislator's will. She arrives at a determinate result compatible with the canc $n$ of interpretation prescribed by the Vienna Convention.

1254 Art. 31 (2) GC is worded as follows:

'(1) The Contracting States shall not impose penalties, on account of their illegal entry or presence, on refugees who, coming directly from a territory where their life or freedom was threatened in the sense of Article 1, enter or are present in their territory without authorization, provided they present themselves without delay to the authorities and show good cause for their illegal entry or presence.

(2) The Contracting States shall not apply to the movements of such refugees restrictions other than those which are necessary and such restrirtions shall only be applied until their status in the country is regularized or they obtain admission into anoth sr country. The Contracting States shall allow such refugees a reasonable period and all the necessary facilities to obtain admission into another country.'

${ }^{1255}$ Davy, 1996, p. 120.

${ }^{1256}$ For an example of such an argument, see Maaßen, 1997, pp. 55-79. 
Davy's argumentation can be further reinforced by the contextual argument drawing on the preamble of the 1951 Refugee Convention and Article 3 (3) of the 1933 Convention developed earlier in this sub-section. Pulling together the various threads, we find that the second stage renders an unambiguous outcome: the question whether non-rejection at the border is embraced by Article 33 GC must be answered in the affirmative.

\subsection{Article 33 GC in the Light of the Dublin Convention}

The inclusionary reading arrived at above can be consolidated by drawing on the acquis. On a sub-regional level, the most important factor in the contemporary interpretation of the territorial applicability of Article 33 GC is probably the 1990 Dublin Convention. Its Article 3 (1) reads as follows:
Member States undertake to examine the application of any alien who applies at the border or in their territory to any one of them for asylum.

This convention has been concluded by the Member States of the European Union as an instrument of international law. The group of its Contracting Parties is thus smaller than the group of Contracting Parties to the GC. If both groups had been identical, the norms in the Dublin Convention would have formed part of the context of Article 33 GC under Article 31 (3) VTC. ${ }^{1257}$ Now, with a strict application of the Vienna Convention, these norms would merely represent a supplementary means of interpretation, although one of a very high relevance.

However, if one narrows the scope of scrutiny to the obligations incumbent on Member States of the EU-which is precisely the delimitation chosen for this work-another approach comes into reach. Instead of asking what constitutes the proper interpretation of Article 33 GC, to be adhered to by all its contracting parties, one may ask what constitutes the proper interpretation of Article $33 \mathrm{GC}$, to be adhered to by the Member States of the European Union. Opting for the latter query, we find that the interpretation of Article $33 \mathrm{GC}$ transmutes into

${ }^{1257}$ In this hypothetical case, it would have been most appropriate to term the norms enshrined in the Dublin Convention as 'relevant rules of international law applicable in the relations between the parties' as related to in Art. 31 (3) (c) VTC. 


\section{CHAPTER 10}

the question of interpreting the Dublin Convention. All parties to the Dublin Convention are also parties to the 1951 Refugee Convention. Therefore, the norms of the 1951 Refugee Convention form part of the context of Article 3 (1) DC.

Under this approach, the matter is clear. Member States of the European Union have taken upon themselves the obligation to process asylum claims filed both at their borders and in-country. ${ }^{1258}$ The rationale of asylum procedures is to single out beneficiaries of the norms in the 1951 Refugee Convention, of which Article 33 GC is one. Thus, the rejection of a protection seeker at the border of a Member State amounts to a violation of the Dublin Convention.

\subsection{Conclusion}

On a universal level, convincing contextual arguments have been advanced that Article 33 GC covers non-rejection at the frontier as well. On the sub-regional level, it merits mention that Member States of the EU have acknowledged the applicability of Article 33 GC at the border. In a treaty provision, they have undertaken to examine asylum applications filed at their borders.

\subsubsection{Article 3 CAT}

\subsection{The Second Stage}

As stated earlier, the wording of Article 3 CAT does not make it entirely clear whether or not this provision also prescribes non-rejection at the frontier. Doctrinal writing on this issue is still rather sparse, mainly due to the fact that the CAT has been adopted only in $1984 .{ }^{1259}$ From the outset, it must be recalled that one cannot solve the question by a simple analogy

${ }^{1258}$ For a confirmation from a governmental perspective, see F. Löper, 'Pre-Procedural Aspects', in UNHCR, 4th International Symposium on the Protection of Refugees in the Central European and Baltic States, 27-29 September 1998, Bled/Slovenia. Report and Proceedings (1999, UNHCR, Geneva), p. 55.

1259 For an extensive reading, see Hartl, 1999, p. 181, with further references to other extensive interpretations. 
to Article 33 GC. ${ }^{1260}$ Apart from the very wording of both provisions, their context and telos is obviously not identical, which prohibits anyy interpretative short cuts.

It has been argued by Maaßen that the drafters of CAT must have been well aware of the terminological dispute embroiling Article 33 GC and that they consciously refrained from choosing an unambiguous wording, also prohibiting rejection at the frontier. ${ }^{1261}$ First, one might wish to recall that this would make the interpretation of Article 3 CAT contingent upon the interpretation of Article 33 GC. As we saw above, the inclusionary reading of the latter provision prevails, which would bring about an inclusionary reading of Article 3 CAT. This is quite the opposite of what Maaßen has intended. Second, it has to be asked what relevance this argument possesses under the Vienna Convention. To be sure, the 1951 Refugee Convention is not part of the context of Article 3 CAT. By way of example, Afghanistan is party to CAT, but not to the 1951 Refugee Convention. It follows that the provisions of the 1951 Refugee Convention do not represent 'relevant rules of international law applicable in the relations between the parties' to CAT. ${ }^{1262}$ Thus, arguments relating to the 1951 Refugee Convention are irrelevant for the purposes of the second stage.

Is there any contextual data that must be taken into account when interpreting Article 3 CAT? It must be underscored that this provision is embedded in a normative environment mainly dealing with the punishment of perpetrators as well as the prevention of torture and other forms of ill-treatment within Contracting States. Article 3 CAT is therefore somewhat atypical, and the possibility of drawing upon other provisions as contextual elements is clearly limited.

However, one might wish to note a reference to Article 7 ICCPR in the preamble of CAT:

The States Parties to this Convention,

[...]

Having regard to article 5 of the Universal Declaration of Human Rights and article 7 of the International Covenant on Civil

\footnotetext{
1260 Weissbrodt attempts to solve the matter by a simple analogy to the 1951 Refugee Convention. Weissbrodt and Hörtreiter, 1999, p. 57.

${ }^{1261}$ Maaßen, 1997, p. 183.

1262 Art. 31 (3) (c) VTC.
} 


\section{CHAPTER 10}

and Political Rights, both of which provide that no one shall be subjected to torture or to cruel, inhuman or degrading treatment or punishment, $[\ldots]^{1263}$

Could this imply that Article $3 \mathrm{CAT}$ is presumed to have at least the same protective scope as Article 7 ICCPR? If the latter covered non-rejection at the border, the former would do so too. This would make the precise content of Article 3 CAT contingent upon the interpretation of Article 7 ICCPR. Nonetheless, the protection from extraterritorial threats inherent in Article 7 ICCPR covers not only torture, but also cruel, inhuman or degrading treatment or punishment. This is obviously not the case with Article 3 CAT, which has been explicitly limited to cover torture only. Therefore, Article 3 CAT cannot be said to replicate the extraterritorial protection afforded under Article 7 ICCPR. Moreover, the language of the quoted preambular recital is rather weak: the phrase 'having regard to' merely denotes that the Contracting Parties had the named provisions in mind, without necessarily reaffirming and drawing upon each and every aspect inherent in them.

However, one might wish to inquire whether Article $3 \mathrm{CAT}$. is part of a seamless system of preventing torture and other specified forms of illtreatment. If that were the case, it would seem logical not to disrupt-by allowing rejection of potential torture victims at the border of host states-the universal coverage provided by such a system. But a seamless system would already be disrupted by the limitation of Article 3 CAT to torture only. Possibly, one could inquire whether the CAT provides seamless protection at least from torture. To be sure, the CAT provides for preventive, punitive and reparative measures with regard to torture. Nonetheless, an argument solely crafted on this basis will not be a very strong one-after all, the very purpose of the present argumentation is to single out the precise limitations of torture protection.

In addition, teleological interpretation is also hampered by the same lack of specific evidence. The preamble does not give further clues, and an inquiry into the object and purpose of Article 3 CAT quickly propels interpretation to very abstract levels. In all, the second stage yields singularly weak arguments, and does not allow for a stable and determinate outcome. Recourse to the third stage is necessary.

${ }^{1263}$ Preamble to CAT, fourth recital. 


\subsection{The Third Stage}

The travaux provide some evidence supporting an inclusionary reading of Article 3 CAT. The original Swedish draft for that provision was worded quite differently:

No State Party may expel or extradite a person to a State where there are reasc nable grounds to believe that he may be in danger of being subjected to torture or other cruel, inhuman or degrading treatment or punishment. ${ }^{1264}$

In the deliberations of the 1979 Working Group, no conclusion could be reached on this proposal. ${ }^{1265}$ Therefore, Sweden presented a revised draft of this provision, which was subsequently adopted and became Article 3 (1) CAT:

No State Party shall expel, return ("refouler") or extradite a person to another State where there are substantial grounds for believing that he would be in danger of being subjected to torture. ${ }^{1266}$

Notably, the words 'return ("refouler")' had been added to the prohibited measures, while the danger of cruel, inhuman or degrading treatment or punishment other than torture was eliminated from the protective scope of the provision. Thus, the revised draft provision simultaneously extended and limited the reach of what would become Article 3 CAT.

The ensuing discussion of the extended wording in the 1979 Working Group is quite remarkable. It was said that there were strong humanitarian reasons to include the English and the French terms. Further, mention was made of the 1951 Refugee Convention, which contained the very same words. On the other hand, it was pointed out that the 1951 Refugee Convention 'concerned a different subject and was not broadly accepted'. ${ }^{1267}$ Finally, and probably most revealingly, it was

1264 J. H. Burgers and H. Danelius, The United Nations Convention against torture: a handbook on the Convention against torture and other cruel, inbuman or degrading treatment or punishment (1988, Martinus Niihoff Publishers, Dordrecht), p. 49.

1265 Burgers and Danelius, 1988, p. 49.

1266 Ibid. The Swedish proposal was intr sduced in UN Doc. No. E/CN.4/WG.1/WP.1.

1267 Burgers and Danelius, 1988 , p. 50. At the time, the 1951 Refugee Convention did not enjoy the same degree of acceptance as it does today, especially in Eastern Europe and in Asia. 


\section{CHAPTER 10}

suggested "that the inclusion of the concept of "return" might require a State to accept a mass influx of persons when it was not in a position to do so'. ${ }^{1268}$

In spite of these misgivings, the revised draft provision was adopted in the 1980 Working Group. ${ }^{1269}$ Contrary to what Maaßen has assumed ${ }^{1270}$, delegations took the term 'return' to imply non-rejection at the border. Otherwise, it would hardly make sense to allude to the risk of an influx. Furthermore, as the Working Group and, later on, the Signatories accepted the inclusion of the terms 'return ("refouler")', it can be validly assumed that this acceptance also stretched over an obligation of admission at the border, irrespective of number of beneficiaries.

Given the fact that the CAT was endowed with a facultative monitoring mechanism allowing for individual complaints, this argument gains additional weight. To wit, Contracting Parties may recognise 'the competence of the Committee to receive and consider communications from or on behalf of individuals subject to its jurisdiction who claim to be victims of a violation by a State Party of the provisions of the Convention'. ${ }^{1271}$ As rejection at the frontier is a jurisdictional act, the path would be open for a rejected person to complain to the CAT Committee. At least those Contracting Parties opting for the mechanism must have been conscious of the fact that any ambiguity in the wording of Article 3 CAT might be construed extensively by the future CAT Committee. ${ }^{1272}$ Although the authoritative power of interpretation would still remain with states, the observations by the CAT Committee would de facto have a considerable impact on the understanding of CAT. This constituted a stark difference to the 1951 Refugee Convention, which could not be invoked by individuals before a specific monitoring body. Therefore, the fact that the drafting delegations chose to retain the terms 'return

\footnotetext{
1268 Burgers and Danelius, 1988 , p. 50.

1269 Burgers and Danelius, 1988, p. 54.

1270 See text accompanying note 1268 above.

1271 Art. 22 (1) CAT.

1272 At the time, the method of dynamic interpretation pursued by the European organs endowed with monitoring the ECHR was well known.
} 
("refouler")' evidences that they were aware of and accepted a possible inclusionary reading of Article 3 CAT by the CAT Committee. ${ }^{1273}$

The assumption of admission obligations was, however, clearly limited in scope. First, as already remarked, Article $3 \mathrm{CAT}$ did not protect from the extraterritorial threat of cruel, inhuman or degrading treatment or punishment. Compared to the implied prohibitions of refoulement in Article 3 ECHR and Article 7 ICCPR, this reduces the protective obligations of Contracting Parties to a great extent. Second, the definition of torture contained in Article 1 CAT is rather demanding, as it contains a specific criterion of intent. Taken together, the number of persons coming under the scope of Article 3 CAT is significantly reduced. This must have dissolved the fears voiced in the 1979 Working Group. ${ }^{1274}$

Although it is not possible to establish a consistent state practice in the sense of Article 31 (3) (b) VTC, the actual comport of states may prove relevant in the third stage. By way of example, in the German Aliens Act, the general prohibition of expulsion to a state where a torture risk exists in Section 53 (1) is explicitly extended to situations arising at the border. ${ }^{1275}$ Chapter 8 Section 1 of the Swedish Aliens Act puts the refusal of entry and expulsion on the same footing:

An alien refused entry or expelled may never be conveyed to a country where there are reasonable grounds for believing that he would be in danger of suffering capital or corporal punishment or of being subjected to torture or other inhuman or degrading treatment or punishment, nor to a country where he is not protected from being sent on to a country where he would be in such danger.

These examples from domestic law may further support the contention that states support an inclusionary reading of Article 3 CAT at present.

Let us sum up. In the third stage, and drawing mainly on the travaux, it has been possible to establish strong arguments militating for an inclusionary reading. Against this background, Article 3 CAT must be

1273 The question of rejection at the border in the light of Art. 3 CAT has not yet been brought before the CAT Committee. This is mainly due to the fact that states de facto observe the prohibition of refoulement when confronted with claims at their borders.

1274 See text accompanying note 1261 above.

1275 Section 60 (5) of the Aliens Act makes Section 53 (1) applicable mutatis mutandis to the refusal of entry. 


\section{CHAPTER 10}

understood to comprise non-rejection at the border of Contracting Parties.

\subsubsection{Article 45 FC}

In the second stage, we were tasked with clarifying the meaning of the verb 'to transfer' as it is used in Article 45 FC.

Are there any contextual elements which may elucidate the proper reading of Article $45 \mathrm{FC}$ ?

Article $1 \mathrm{FC}$ states that ' $[\mathrm{t}] \mathrm{he}$ High Contracting Parties undertake to respect and to ensure respect for the present Convention in all circumstances'. The phrase 'in all circumstances' may be taken to suggest that it is improper to infer limitations from the Convention text, which are not explicitly stated in it. This is reinforced by the language of Article $45 \mathrm{FC}$, which states that transfer may take place 'in no circumstances'. Further, the heading of Section II, of which Article 45 FC forms part, reads 'Aliens on the territory of a party to the conflict'. As earlier mentioned, rejection at the border usually takes place on the territory of the State where entry was requested. Therefore, the phrase 'in no circumstances' must be understood to include rejection at the border.

At first sight, the widely respected Commentary to the Fourth Convention seems to confirm this reading: 'Any movement of protected persons to another State, carried out by the Detaining Power on an individual or collective basis, is considered as a transfer for the purposes of Article $45^{\prime} \cdot{ }^{1276}$ Obviously, this statement is the product of a contextual interpretation. The Commentary continues:

The term "transfer", for example, may mean internment in the territory of another Power, repatriation, the returning of protected persons to their country of residence or their extradition. The Convention makes provision for all these possibilities.

Suddenly, this exemplification turns into an exhaustive listing, when the Commentary states:

1276 Pictet, 1958, p. 266. 
On the other hand there is no provision concerning deportation (in French "expulsion"), the measure taken by a State to remove an undesirable foreigner from its territory. In the absence of any clause stating that deportation is to be regarded as a form of transfer, this Article would not appear to raise any obstacle to the right of Parties to the conflict to deport aliens in individual cases when State security demands such action. However, practice and theory both make this right a limited one: the mass deportation, at the beginning of a war, of all the foreigners in the territory of a belligerent cannot, for instance, be permitted. ${ }^{127}$

The method used herein begs questions. The exclusion of expulsions from the scope of the provision relies on an argument e contrario: as expulsion is not explicitly mentioned, it must be assumed that Article $45 \mathrm{FC}$ applies to it. Neither the wording nor the structure of the provision suggests that the prohibition of refoulement is limited to those practices mentioned in other paragraphs of the Article. In other words, these practices do not form an exhaustive list. Had that been the case, it would have been quite meaningless to introduce the prohibition of refoulement with the phrase 'in no circumstances', added to the prohibition of refoulement. The quoted argumentation is simply unconvincing.

Moving on to a purely teleological interpretation, we face the same difficulties as already encountered with human rights instruments. It is quite clear that the Geneva Conventions are inspired by the wish to maximise the protection of the individual. At the same time, it is clear that states wished to draw the line with regard to their responsibilities. Thus, the telos alone does not help to establish an interpretative presumption-be it in favour of individual beneficiary or protectionburdened states.

The contextual elements adduced earlier, however, are sufficient to establish clarity in the second stage: Article $45 \mathrm{FC}$ must be understood to prohibit rejection at the border as well.

1277 Ibid. 


\subsubsection{Implicit Prohibitions of Refoulement}

We have earlier concluded that a specific risk of human rights violations in third countries blocks the removal of a claimant, present on the territory of a host state, to such a third country. However, this does not necessarily answer the question whether Contracting Parties to the ECHR and ICCPR have to admit persons threatened with pertinent human rights violations elsewhere to their territories. The important difference consists of the fact that the latter group of persons is still outside the territory of Contracting Party.

\subsubsection{Article 7 ICCPR}

Regarding protection claims made from outside the territory of a Contracting Party, the parallels between the ECHR and the ICCPR cease to exist. To be sure, the ICCPR does not provide for such claims. This flows from a contextual argumentation. Article 2 (1) ICCPR expressly requires that the individual claimant be "within its territory and subject to its jurisdiction'. ${ }^{1278}$ This contextual argument clarifies the matter: Article 7 ICCPR cannot be invoked if the claimant lacks territorial contact with the potential host state.

With regard to protection claims made at the border of a Contracting Party to the ICCPR, the wording of Article 2 (1) ICCPR is unambiguous. As long as the claimant is physically in touch with the territory of that Contracting Party, she falls under the protective ambit of Article 7 ICCPR.

1278 Nowak first affirms that presence on state territory and subjugation to state jurisdiction is crucial for individual protection under the ICCPR. However, Nowak also points at the contradictions inherent in this cumulative requirement (e.g. that a state would not be responsible for denying the right to entry to a citizen outside its territory) and suggests a teleological interpretation to resolve them. Moreover, he suggests that recourse should be taken to the extent of state responsibility when determining the precise meaning of Art. 2 (1) ICCPR. Nowak, 1989, p. 45. At first sight, his argumentation could be taken to support a state responsibility to allow access to protection seekers outside its territory. In the opinion of this author, Art. 31 (4) VTC must be taken into account, which would provide a powerful counter-argument to such an extensive reading. See also Goodwin-Gill, 1996, p. 142, invoking dicta of the Human Rights Committee in support of an extraterritorial application of the ICCPR. 
In both cases, contextual arguments could bring about a determinate outcome. The ICCPR provides no right to access for persons not in touch with the territory of the Contracting Party.

\subsubsection{Article 3 ECHR}

When delimiting the scope of the ECHR, its drafters discarded the criterion of territorial presence and resorted only to the criterion of jurisdiction. Article $1 \mathrm{ECHR}$ is worded as follows:

The High Contracting Parties shall secure to everyone within their jurisdiction the rights and freedoms defined in Section 1 of this Convention.

For reasons of argumentative economy, we shall first scrutinise the impact of that solution on protection claims made outside the territory of Contracting Parties. If they fall within the ambit of the ECHR, an argument a fortiori would imply that protection claims made at the border do so as well. If not, we would be compelled to look into the issue of claims at the border separately.

In 1981, the European Commission delimited the scope of Article 1 ECHR in some detail. Its pertinent reasoning, drawing on the case law of the Court as well as its own earlier decisions, merits quoting at some length.

The Commission recalls that, in this provision, the High Contracting Parties undertake to secure the rights and freedoms defined in Section I to everyone "within their jurisdiction" (in the French text: "relevant de leur juridiction"). This term is not equivalent to or limited to the national territory of the High Contracting Party concerned. It emerges from the language, in particular of the French text, and the object of this Article, and from the purpose of the Convention as a whole, that the High Contracting Parties are bound to secure the said rights and freedoms to all persons under their actual authority and responsibility, not only when the authority is exercised within their own territory, but also when it is exercised abroad. [...] As stated by the Commission in Application Nos. 6780/74 and $6950 / 75$, the authorised agents of the State, including diplomatic or consular agents and armed forces, not only remain under its 


\title{
CHAPTER 10
}

\begin{abstract}
jurisdiction when abroad but bring any other persons or property "within the jurisdiction" of that State, to the extent that they exercise authority over such persons or property. In so far as, by their acts or omissions, they affect such line with persons or property, the responsibility of the State is engaged. ${ }^{1279}$
\end{abstract}

Thus, in our terminology, the term 'within the jurisdiction' does not refer to a geographical, but to an administrative boundary, and the administrative reach of a state exceeds its territorial borders. Be it within or outside state territory-wherever the state or its agents act or omit to actits responsibility under the ECHR can be engaged.

Let us now merge these two lines of argument. First, we have concluded that State Parties to the ECHR must accord extraterritorial protection to persons present on its territory by not removing them to countries where protection-relevant threats are situated. ${ }^{1280}$ Removal is an act of state authority, affecting a person under the jurisdiction of the removing state. It is covered by Article $1 \mathrm{ECHR}$, as expounded earlier. This conclusion could be reached in the second stage of interpretation, relying mainly on a contextual argumentation.

Second, following the argumentation of the Commission, Article 1 ECHR also obliges states to protect the rights guaranteed in Section 1 in the exercise of their authority outside state territory. A person in need of extraterritorial protection requesting entry into a state is under the authority of that state as far as the demand of entry is concerned. Those rights that may trigger extraterritorial protection are all rights guaranteed in Section I. Any act or omission by the demanded state relating to the entry demand affect that person. Thus, such acts or omissions may engage the responsibility of the requested state under the ECHR. Accordingly, there is no difference between removal and denial of entry with regard to state responsibility under Section I. Paraphrasing the words of the Court in Cruz Varas, one may state the following. In so far as any liability under the Convention is or may be incurred, it is liability incurred by the Contracting State denying entry by reason of its having taken action which has as a direct consequence the exposure of an individual to proscribed ill-

1279 Dec. Adm. Com. Ap. 9360/81, 28 February 1983, D\&R 32 p. 211 (214-6), para. 14. To support its reasoning in this passage, the Commission refers back to a number of earlier decisions.

${ }^{1280}$ See chapter 10.1.1.4 above. 
treatment. ${ }^{1281}$ To be sure, such an obligation is a negative one: the Contracting State may not hinder entry by jurisdictional acts or omissions. If that state routinely blocks access to its territory by imposing visa requirements for certain nationalities, it has to waive that requirement in relevant cases.

For protection claims filed at the border of Contracting Parties, a corresponding argumentation implies that a duty not to inhibit access to the said Party's territory flows from Article 3 ECHR.

Otherwise put, Article 1 ECHR entails a privilege of entry for aliens threatened by torture or other forms of ill-treatment covered by the ambit of Article 3 ECHR. The term 'privilege' is used in the Hohfeldian sense here-it implies that a State Party to the ECHR has no right to impose visa requirements on such an alien. Let us exemplify. A person risking torture in her home country approaches the Swedish Embassy in its capital, asking for an entry visa. Provided that the denial of an entry visa has the direct consequence of exposing that person to torture, the Swedish consular officer must issue it, if Sweden is not to violate Article 3 ECHR. Technically speaking, the present conclusion is a mere consequence of the prevailing universalist reading of Article $3 \mathrm{ECHR}$ in the sub-sections on protection. It draws on the determinacy won in that argumentation.

It cannot be denied that this conclusion unfolds the most radical consequences for European migration policies. Together with complementary measures (carrier sanctions and pre-frontier training and assistance), visa requirements remain the most powerful device of migration control. Their track record of deflecting would-be refugees is considerable, reaching back to the German refugee crisis of the 1930s. On a political level, it has been constantly argued by UNHCR and nongovernmental organisations that such requirements are an indiscriminate means of control, blocking access even for those persons in need of protection. Drawing on the argumentation developed in this chapter, it is now possible to argue that an indiscriminate application of visa requirements is illegal under the ECHR.

This conclusion is radically at odds with the current practices of many Contracting Parties to the ECHR. In the EU, far from all Member States operate a regime allowing protection seekers to file claims under Article 3

1281 See text accompanying note 1161 above. 
ECHR with diplomatic representations abroad. ${ }^{1282}$ This endangers their compliance with their human rights obligations flowing from the ECHR.

\subsection{Interim Conclusion on Hard Cases}

In order to facilitate further discussion, we shall finish by pulling together the main results of the second and third stages. Finally, it shall also be asked how the material outcome affects our further inquiry.

Setting out with the first question on protection, we can state that almost all of the ambiguities persisting at the first stage could be clarified at the second stage. Proceeding to the third stage was necessary only in two cases (the applicability of Article $3 \mathrm{CAT}$ to non-rejection at the border and immigration under Article 12 ICCPR), of which the latter resulted in an indeterminate outcome. An overview of the results derived from the second and third stages is given in Table 7 below.

Moving on to the second question of access to territory, it was determined that all explicit prohibitions of refoulement (Article 33 GC, Article 3 CAT and Article 45 FC) contain an obligation of non-rejection at the border. Contrary to various particularist arguments, these provisions feature a punctual right to access. However, this right is only applicable on the territory of a Contracting Party, and cannot be invoked by a person present in another state. Thus, the named provisions cannot be used to obtain a waiver from visa requirements in order to evade the situations of threat specified in the three provisions.

Moving on to the remaining provisions, the second stage produced remarkable results with regard to Article 3 ECHR. This provision indeed implies a prohibition of removal, thus confirming the reasoning of the European Court of Human Rights, as well as a punctual right to access at the border and from elsewhere (issues hitherto not deliberated by the Court). The importance of this outcome can hardly be underestimated. Mainly due to its monitoring mechanism and the respect it enjoys, the ECHR remains the most powerful human rights instrument available in the region. Provided the preconditions for the applicability of Article 3 ECHR are fulfilled, a Contracting Party to the ECHR is not only legally required to mete out protection. Over and above that, it is also obliged not to obstruct access to its territory, e.g. by demanding an entry visa.

1282 See notes 522 and 523 above. 
Given that visa requirements are the prime tool of regulating access to extraterritorial protection in contemporary Europe, this outcome should have considerable practical repercussions on regional asylum and migration policies. Although this interpretation is a stable product of the interpretative rules contained in the Vienna Convention, it opens a justificatory question: where are the limits of the protective obligations relating to extraterritorial threats under the ECHR? This issue shall be pursued in detail in the ensuing chapter.

The ECHR remains, however, the only instrument covering protection as well as both modes of access. While Article 7 ICCPR allows for protection on the territory as well as non-rejection at the border, its scope does not include persons situated elsewhere.

It is also worth noting, however, that some interpretations at the second stage entailed voluminous and complex arguments, as was the case with the protection and access dimensions of Article $3 \mathrm{ECHR}$ as well as the access dimension of Article 33 GC. Materially speaking, though, it is hardly surprising that the issue of access raises profound conflicts, which can be tidied up only with great effort-or not at all. The only issue remaining indeterminate after the second and the third stage was whether Article 12 ICCPR provides for a temporary right to immigration. Both the universalist and the particularist position could be fortified with complex argumentations, and a weighing operation turned out to be inevitable. This is the second theme for further inquiry: can this indeterminacy be solved beyond interpretation, e.g. by introducing some form of presumption? If not, what does it do to law as a whole, given that the issue at stake is far from being trivial? 


\begin{tabular}{|c|c|c|c|}
\hline & $\begin{array}{l}\text { Claimant is } \\
\text { situated within } \\
\text { the territory of } \\
\text { a potential host } \\
\text { state }\end{array}$ & $\begin{array}{l}\text { Claimant is } \\
\text { situated at the } \\
\text { border of a } \\
\text { potential host } \\
\text { state }\end{array}$ & $\begin{array}{l}\text { Claimant is } \\
\text { situated } \\
\text { elsewhere }\end{array}$ \\
\hline Art. 33 GC & Yes (1st stage $)$ & Yes (2nd stage $)$ & No (1st stage) \\
\hline Art. 3 CAT & Yes (1 $1^{\text {st }}$ stage $)$ & Yes (3rd stage) & No (1st stage) \\
\hline Art. 45 FC & Yes (1st stage) & Yes (2 $2^{\text {nd }}$ stage $)$ & No (1st stage) \\
\hline Art. 3 ECHR & Yes (2 $2^{\text {nd }}$ stage $)$ & Yes (2 $2^{\text {nd }}$ stage $)$ & Yes (2nd stage) \\
\hline Art. 7 ICCPR & Yes (2nd stage $)$ & Yes (2nd stage $)$ & No (2nd stage) \\
\hline Art. 32 FC & No (1 st $^{\text {stage })}$ & No (1 st $\left.^{\text {stage }}\right)$ & No (1st stage) \\
\hline
\end{tabular}

Table 7: Applicability ratione loci of Selected Norms in Relation to a Potential Host State. Results of the First, Second and Third Stage.

\subsection{Substance by Method?}

\subsubsection{What Does the Vienna Convention Do To the Law?}

In the preceding interim conclusions, we have pulled together the material outcome of a number of interpretations. However, reaching this outcome raised a new question. To wit, what did the strict pursuit of Articles 31-2 VTC do to our material or, put generally, what do these articles do to any legal material?

The interpretative provisions of the Vienna Convention structure interpretative data by assigning them specific places in a hierarchy. This is helpful in two ways. First, irrelevant, i.e. non-legal, arguments are 
eliminated. ${ }^{1283}$ Second, procedural rules for the controlled escalation of complexity in interpretation are provided. To overcome ambiguity, the amount of data accessible to the interpreter is increased step by step. It is reasonable to assume that the conflicts identified and persistent in the first stage will come into full bloom in the remaining stages of the interpretative operation. Yet, with an increasing total amount of data, chances augment that data critical for the elimination of competing positions come within reach. Ultimately, the goal of interpretation is to use the increased amount of data for the purpose of reduction. The underlying logic is to expand complexity for the purpose of reducing it. This would only work if there were no 'residual data' which would not be consumed by reduction. The ideal would be to expand the data amount exactly so much as to induce one single outcome, consuming all data made available. However, the requirement of neutrality inherent in a legally framed procedure prohibits that only such data is made available that would resolve ambiguity in a determinate manner. Neutrality dictates that not single data, but rather classes of data (as the 'context' or the 'telos') are gradually made available to the interpreter. In these classes of data, irreducible elements may be contained. These would then augment complexity instead of reducing it, resulting in ever more profound ambiguity.

To conclude, a materially neutral methodology of interpretation cannot guarantee determinate outcomes. This does not imply that it is useless, however. What it can do, and should do, is to structure legal argumentation, to do away with simple ambiguities, to diminish the necessity of weighing conflicting principles and, finally, to single out the point in argumentation at which political decisions are cloaked in the attire of formal implementation of interpretative rules.

However, the rules of the Vienna Convention are not necessarily neutral when it comes to balancing the letter of the law and the will of the legislator. The procedure of interpretation outlined above gives the letter of the law a strategic advantage over the context, telos and other manifestations of the will of the legislator. This advantage can be compared to that enjoyed by the chess player making the first move. It also offers such an advantage to the context and telos in their relation to

1283 Properly, one might wish to speak of arguments that are not legally coded. However, the question whether all arguments can be translated into legal arguments is not at stake here. 


\section{ChAPTER 10}

other manifestations of the legislator's will, as, for example, the travaux. This hierarchy may impact most decisively on the outcome of a specific interpretation, and, as we have seen earlier, a versed interpreter usually takes it into account when crafting arguments.

The methodology offered by the Vienna Convention is no selfpropelling machinery, however. It remains dependent on decisions taken by the interpreter. To wit, the assessment of clarity after the first and second stage respectively is a critical area. ${ }^{1284}$ As clarity is a vague concept, here is the possibility of manipulating the outcome of interpretative operations. Above, we have opted for a formal concept of clarity, implying the absence of arguable counter-arguments admissible in a given stage of interpretation. ${ }^{1285}$ Yet, while this concept is logically derived from the Vienna Convention, it is not prescribed by it. We have to acknowledge that other concepts of clarity can be devised and defended, and may eventually lead to different outcomes.

\subsubsection{What Do Lawyers Do With the Vienna Convention?}

As a by-product of our own interpretation, we were forced to conclude that the majority of interpretative efforts by doctrinal writers as well as within monitoring bodies partly or fully neglect the methodological framework prescribed by the Vienna Convention. On a formal level, this is serious, as the Vienna Convention is a binding instrument, and the international lawyer has no choice but to follow its rules of interpretation. But what are the reasons for this neglect? Why is the positivist potential of international law not fully exploited when it comes to the cutting-edge exercise of interpretation?

It is conceivable that some lawyers perceive the material and structural limitations flowing from the Vienna Convention as simply impeding their argumentative project. Such lawyers may believe that an unrestrained presentation of interpretative arguments is the better success strategy. Or they believe that following a different canon of interpretation (e.g. one

\footnotetext{
1284 There are others: as an example, what exactly is to be considered as the 'text of the treaty' or what is to be counted as 'subsequent practice in the application of the treaty which establishes the agreement of the parties regarding its interpretation'?

1285 See text accompanying note 1200 above on the combination of a determinate context and an indeterminate telos in the second stage.
} 
putting more emphasis on the intent of the legislator) secures an outcome more favourable to their needs. Obviously, such wholesale circumvention of the Vienna Convention makes an interpretation derived on its basis extremely weak and contestable. Put succinctly, it reveals a lawyer disregarding the law. In the present context, this approach is without theoretical interest and merits no further discussion.

More interesting is the class of lawyers who use the Vienna Convention as a strategic tool in their material argumentation. Above, we saw how doctrinal writers became ever more aware of the trump role played by the Vienna Convention. They reformulated older arguments, thus moving them up to a better position in the three stages of interpretation. ${ }^{1286} \mathrm{Or}$ they sought to transform teleological arguments into contextual ones ${ }^{1287}$, thus making them more concrete and protecting them from being consumed in the opposition of a universalist and a particularist telos. Used likewise, the Vienna Convention becomes a tool in a partisan struggle. This is wholly acceptable-legal argumentation does not take place in a political void, but is part and parcel of a greater context. As long as arguments can be cloaked in the language of law, they enjoy a privileged position in discourse. But beyond partisan conflict, the question remains whether the law favours, or indeed implies, a certain outcome.

\subsubsection{Three Wildcards: Presumptions, Telos and Indeterminacy}

Some doctrinal writers had a ready-made answer in store. They operated openly with presumptions on an implicit burden of proof, a method highly reminiscent of a standard framework in civil procedure law: if the universalist claimant does not succeed in the creation of determinacy, she shall lose the case. Otherwise put, if interpretation does not produce a clear and unambiguous outcome, a certain paradigm shall prevail, and the opposite paradigm shall lose the case. One author operated with the maxim in dubio mitius to support state interests: where an obligation cannot be unambiguously shown to exist, it shall be assumed that states

\footnotetext{
1286 Consider e.g. the reformulation of a travaux-based argument on the applicability of Art. $33 \mathrm{GC}$ to rejection at the border into a contextual argument grounded in the Final Act. See text accompanying note 1237 above.

1287 See text accompanying note 1254 above.
} 


\section{CHAPTER 10}

are not obliged. ${ }^{1288}$ But in dubio mitius can also be turned around and put to work for the universalist. This would imply the opposite presumption: any doubt would support the deduction of a state obligation. Clearly, if such presumptions had had a basis in international law, they would open good chances to secure an outcome that is determinate. Presumptions are thus serving two groups: those favouring their underlying paradigm, but also those cherishing determinacy. However, none of the authors using such presumptions bother to clarify their validity and justification under international law. While the operation of presumptions based on some sort of intuition must be rejected, the question remains: does international law contain an inherent presumption apt to endow interpretative stalemates with determinacy? And, if this is the case, does it work for universalism or particularism?

The use of presumptions can take on a more subtle form. We have noted above that some authors convert the telos into a Trojan horse, bringing their own preferences into the second stage of interpretation. ${ }^{1289}$ As shown earlier, there is no simple answer to the question how the goal of promoting human rights is best served. Therefore, teleological interpretation easily leads back to the original conflict between universalism and particularism. If any hierarchy between the two paradigms could be established, this would impact on the second stage of interpretation, either tilting outcomes in its favour, or, where counteracting contextual arguments exist, producing an indeterminate outcome. Basically, teleological reasoning raises the same questions as the issue of presumptions.

There is a third manifestation of the very same question. In the present chapter, the Vienna Convention was perceived as a tool producing determinate outcomes-no matter whether these work for the particularist or the universalist. The underlying assumption was the desirability of determinacy at the earliest possible stage in interpretation. This determinacy was to be produced without resort to presumptions. By consequence, if the Vienna Convention failed to produce a determinate outcome, there would simply be no determinate outcome, and one of the two promises of law-justice and predictability-would remain unfulfilled.

\footnotetext{
1288 See text accompanying note 1192 above.

1289 See text accompanying note 1236 above.
} 
As we have seen, this worst case scenario materialised with regard to the contested right to immigration under Article 12 ICCPR.

Now, what are the consequences of an indeterminate interpretation? The issue of determinacy is one of partisanship as well. Are not indeterminate outcomes simply supportive of existing power structures? Would not an indeterminate outcome support that paradigm which happens to dominate political discourse for the moment? Regarded as such, is indeterminacy nothing more than a nicely camouflaged way of taking sides?

This chapter set out to scrutinise how the conflict between universalism and particularism manifests itself in the interpretation of the law regulating protection and access. Faced with these manifestations, we were compelled to realise that we cannot do without an answer to this conflict. In reality, the three issues beyond the reach of the Vienna Convention-the existence of a presumption, the handling of the telos and the consequences of indeterminacy-boil down to one. Directly or indirectly-does international law favour universalism or particularism? Without an answer, the meaning of law remains obscure. 